\title{
Financing Constraint and Firm-Level Investment Following a Financial Crisis in Indonesia
}

\author{
Agustinus Prasetyantoko
}

Juillet 2007

GATE Groupe d'Analyse et de Théorie Économique UMR 5824 du CNRS

93 chemin des Mouilles - 69130 Écully - France

B.P. 167 - 69131 Écully Cedex

Tél. +33 (0)4 72866060 - Fax +33 (0)4 72866090

Messagerie électronique gate@gate.cnrs.fr

Serveur Web : www.gate.cnrs.fr 


\title{
Financing Constraint and Firm-Level Investment Following a Financial Crisis in Indonesia
}

\author{
Agustinus PRASETYANTOKO
}

\begin{abstract}
This paper deals with the sensitivity relation between firm investment and internal liquidity by splitting samples into two different groups of firm, namely the tradable $(T)$ and non-tradable $(N)$ sectors. This paper finds that during boom periods, there is no significant financial constraint on the $T$ and $N$ sectors. In post-crisis periods, it seems that both sectors also have no significant important problem in their internal finance. Both sectors basically move comparably. The main finding is relatively different with several theoretical predictions, especially Tornell and Westermann (2002a, 2004), in which the T-sector would be predicted as experiencing less financial constraint in burst period. However, we find that debt is important variable for sustaining investment in Indonesia. By employing panel data analysis, the findings of this study can shed light on the financing behavior of listed companies in Indonesia, as well as on their investment behavior in the midst of financing constraints and credit market imperfections. The study's sample contains 147 companies listed on the Jakarta Stock exchange for at least 5 five consecutive years between 1994 - 2004.
\end{abstract}

Key words: asymmetric financing opportunities, financing constraint, firm investment, financial crisis

JEL Classification: D2, E51, G31

\footnotetext{
* Member of GATE (Groupe d'Analyse et de Théorie économique) - CNRS UMR 5824. PhD Student in Economics, Ecole Normale Supérieure - Lettres et Sciences Humaines (ENS - LSH), Lyon - France. And Lecturer at Atma Jaya Catholic University, Jakarta, Indonesia. Correspondence: 15 parvis René-Descartes, BP 7000 69342, Lyon cedex 07 France. Email: aprasety@ens-lsh.fr

I am very indebted to Professor Alain SAND from GATE \& ENS-LSH, for the comment and supervision. Thank to participants of $23^{\text {rd }}$ International Symposium on Money, Banking and Finance, 22-23 June 2006, Lille, France. Also thanks to Kim HAJEK from CEREL, ENS-LSH, Lyon for the English language advice. All remaining errors are my own.
} 


\section{Introduction}

From the academic point of view, the 1997 Asian crisis is a challenging "puzzle", inspiring research efforts in many fields of study. Studies on both theoretical and empirical levels have been employed to understand this recent crisis, which is referred to as a thirdgeneration crisis. Nonetheless, research on it is still far from exhaustive due to the phenomenon's intricacy.

This paper proposes an explanation centered on micro-level evidence of the macroeconomic vulnerability arising from the asymmetry in financing opportunities between the tradable $(\mathrm{T})$ and non-tradable $(\mathrm{N})$ sectors in Indonesia. For this issue, Tornell and Westermann (2002a) propose an interesting explanation: "Many countries that have liberalized their financial markets, have witnessed the development of lending booms sometimes ended with a twin currency and banking crises and is followed by a protracted credit crunch that outlives a short-lived recession." They identify two pivotal problems as the main sources of common crises in developing countries, namely risky currency mismatch and asymmetric financing opportunities across the T-sector and $\mathrm{N}$-sector.

This paper deals with the latter issue, which is the asymmetric financing opportunity available to the $\mathrm{T}$ - and $\mathrm{N}$-sectors at the onset and in the aftermath of a crisis. Related to this issue, Tornell and Westermann (2002a, 2002b, and 2004) further explain the coincidence of credit market imperfections and asymmetric sector development as a common phenomenon in middle-income countries (MICs) that leads to financial fragility. For countries concerned, in the period of lending booms, the N-sector grows faster than the T-sector, but inversely, the Nsector recovers more slowly than T-sector in the period of credit crunch following a financial crisis. ${ }^{1}$

In line with this explanation, this paper poses a fairly simple question: whether the Nsector has more financial constraints than the T-sector following a financial crisis in Indonesia. This question will be addressed by examining firm-level investment sensitivity with its internal liquidity or cash flows, with samples split into two different groups. ${ }^{2}$ The findings of this empirical study should be important in explaining macroeconomic vulnerability, since firm-level investment is a pivotal variable in the macroeconomic fluctuation or business cycle.

\footnotetext{
${ }^{1}$ An important indication of the presence of credit crunch is a decline in the ratio of credit to GDP.

${ }^{2}$ This study is inspired by Espanol (2005), which employed the discrimination between the tradable and non-tradable sectors in analyzing Argentinean firms around financial crises.
} 


\section{Financing Constraint in Indonesia: Some Stylized Facts}

Indonesia is a country experiencing a relatively slow economic recovery from the depth and breadth of crisis which was sparked towards the end of 1997. In 2004, compared to other countries in the Southeast Asian region, real GDP growth in Indonesia was relatively low: Indonesia had $4.9 \%$ real GDP growth, while Thailand had $6.2 \%$, the Philippines $6.0 \%$ and Malaysia $7.1 \%{ }^{3}$. Data released by the World Bank shows that following the 1997 shocks, Indonesia's economic performance was weaker than the average performance of East Asian countries. In Q-4 2001, Indonesian real GDP growth was $1.0 \%$, whereas the average growth in East Asian countries was 4.3\%.

After having high economic growth for a decade, Indonesia faced a serious upheaval in economic performance. ${ }^{4}$ The dismal performance of Indonesia's economy was started by the presence of extreme shocks due to the 1997 financial crisis. Indonesia is a country experiencing a deep crisis, with GDP growth reaching minus (-) $13 \%$ and inflation reaching $58.5 \%$ at the end of 1998. Meanwhile, to cope with the high currency depreciation, Bank Indonesia as a monetary authority raised monthly interest rates on time deposits to $70.44 \%$ in August $1998 .^{5}$ Accordingly, the interest rate on credit was also increased to a significant level following the interest rate on time deposits. In such conditions, there were no firms which could survive and continue their activities normally. Approximately one half of Indonesian corporations became technically insolvent due to currency depreciation accompanied by tight monetary and high interest-rate policies.

In Graph 1, we can see that the monthly interest rate on investment, working capital, and deposits rose sharply. Monthly time deposits show the greatest increase since the main objective of this type of policy is to absorb money from the market to avoid speculative actions in the exchange-rate market by money holders.

\footnotetext{
${ }^{3}$ Data taken from East Asia Update: Solid Growth, New Challenges, published by the World Bank, March 2006, page 8. The average real GDP growth over eight countries (Indonesia, the Philippines, Malaysia, Thailand, Hong Kong, Korea, Singapore and Taiwan, China) quoted in this report is $6.6 \%$, which is higher than real GDP growth in Indonesia (4.9\%).

${ }^{4}$ In 1993, the World Bank considered Indonesia as one of the best performing countries in the world with about $7 \%$ economic growth over several years. Indonesia is one of the East Asian Miracles. See World Bank Policy Research Reports titled "The East Asian Miracle: Economic Growth and Public Policy", Washington DC., 1993.

${ }^{5}$ On August $14^{\text {th }} 1997$, the monetary authority in Indonesia decided to adopt a free-floating exchange rate policy since the depreciation of Rupiah was very high. The Indonesian Rupiah (IDR) depreciated sharply against the United States Dollar (USD); from 4,950 IDR/1 USD in December 1997 to 15,000 IDR/1 USD in June 1998.
} 
Stylized fact 1 . The exchange rate depreciation followed by high interest-rate has jeopardized the corporate or real sector balance sheet conditions through multiple channels. On one hand, the corporate sector cannot repay their credit and re-access loans from banks because of the increase in interest rates, but on the other hand, they encounter augmented production costs, especially for import input industries, and declining returns or profitability due to decreasing market demand.

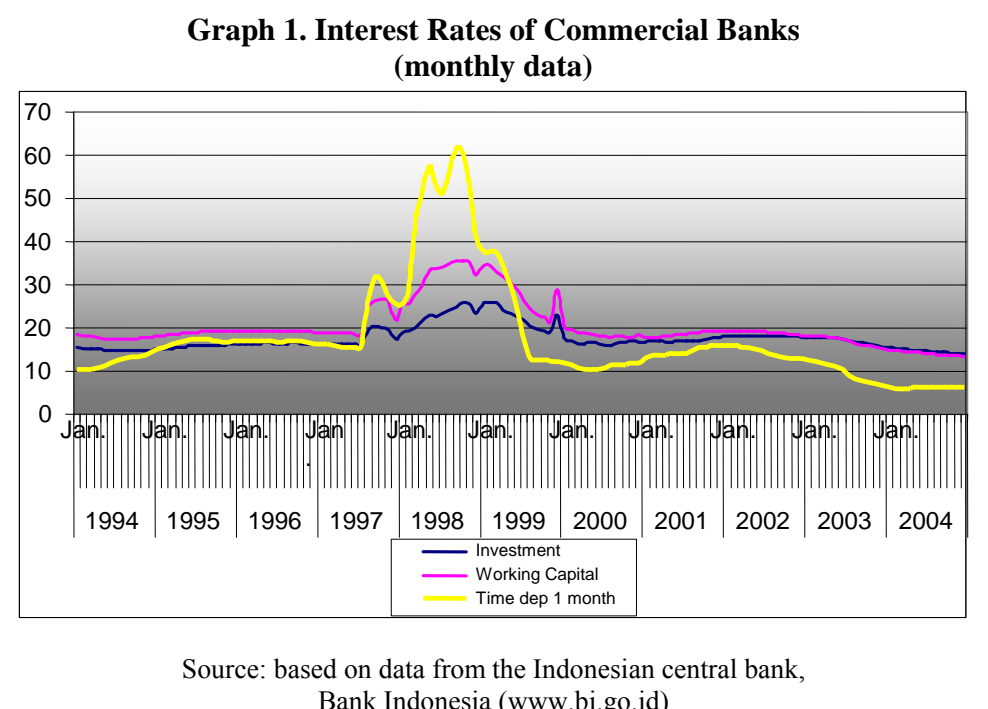

In emerging countries, bank credit plays a very important role in firms' expansion, since capital market institutions are considerably underdeveloped. Under such conditions, monetary policies directly impact upon corporate sector healthiness. Money supply from banking institutions should decrease significantly when interest rates are high, since the corporate sector could not repay loans with such high interest payments. At the same time, due to financial difficulties, the corporate sector experiences worse balance sheets due to the deterioration of the debt-equity ratio as well as of internal liquidity.

In Indonesia, following the 1997 financial crisis, the corporate sector performed poorly, with investment levels still in collapse. Instead of expanding their investment, firms preferred to consolidate their activities first. It is likely that the poor performance of firm-level investment was strongly impacted by tight money policies applied by Bank Indonesia in dealing with exchange rate volatility. ${ }^{6}$ However, it is not the only factor influencing the gloomy condition of business activities in Indonesia after the crisis.

\footnotetext{
${ }^{6}$ The tight money policy employed by Bank Indonesia has become a point for debate, since this policy was required by the International Monetary Fund (IMF) whose policies were not, however, in line with what really
} 
In July 1999, due to the strengthening of economic conditions, Bank Indonesia downgraded the interest rate to $13.8 \%$ (see Graph 1). It is therefore evident that after July 1999, Indonesia's state of crisis was eased. This was due to macroeconomic conditions which were relatively stable, in terms of inflation, the exchange rate, and interest rates. Nevertheless, the decrease in interest rates failed to support real sector recovery. It seems that the supply of credit from the banking sector was not channeled into the real sector. The question is whether it was caused by the inability of the real sector to absorb credit supply or rather by the unwillingness of the banking sector to offer credit.

In Graph 2 it is shown that the outstanding investment credit of commercial banks in domestic currency is dominated by the non-tradable sector. In the boom periods, the gaps between the credit given to the tradable $(\mathrm{T})$ and non-tradable $(\mathrm{N})$ sectors are high; this discrepancy diminished during the crisis period, but it again grew after several years of crisis.

Graph 2. Outstanding Investment Credit of Commercial Banks in Local Currency (in Billions of Rupiah)

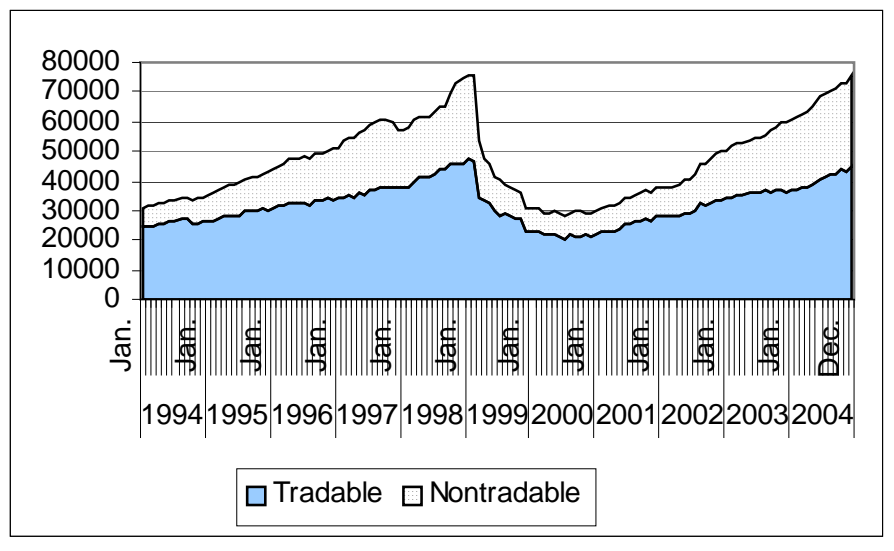

Source: based on data from the Indonesian central bank, Bank Indonesia (www.bi.go.id)

In Graph 3 we can see that investment credit in foreign currency from commercial banks to the non-tradable sector is more volatile than credit to the tradable sector. During the crisis, the foreign currency debt of firms in the non-tradable sector increased significantly and exceeded the credit to firms in the tradable sector. It may that tradable sector firms have greater opportunities to access the capital market or commitments from lenders to reschedule

happened in Asian countries during the crisis. For this issue, see Iwan Jaya Azis, "What Would Have Happened in Indonesia if Different Economic Policies Had Been Implemented When the Crisis Started?", Asian Economic Papers, volume 1, Issue 2, Spring 2002. And also Iwan Jaya Azis, "Modelling Crisis Evolution and Counterfactual Policy Simulations: A Country Case Study”, ADB Institute Working Paper Series, No.23, August 2001. 
their foreign-currency credit, than firms in the non-tradable sector. This effect is also attributable to the fact that tradable sector firms may receive returns in foreign currencies due to their export activities.

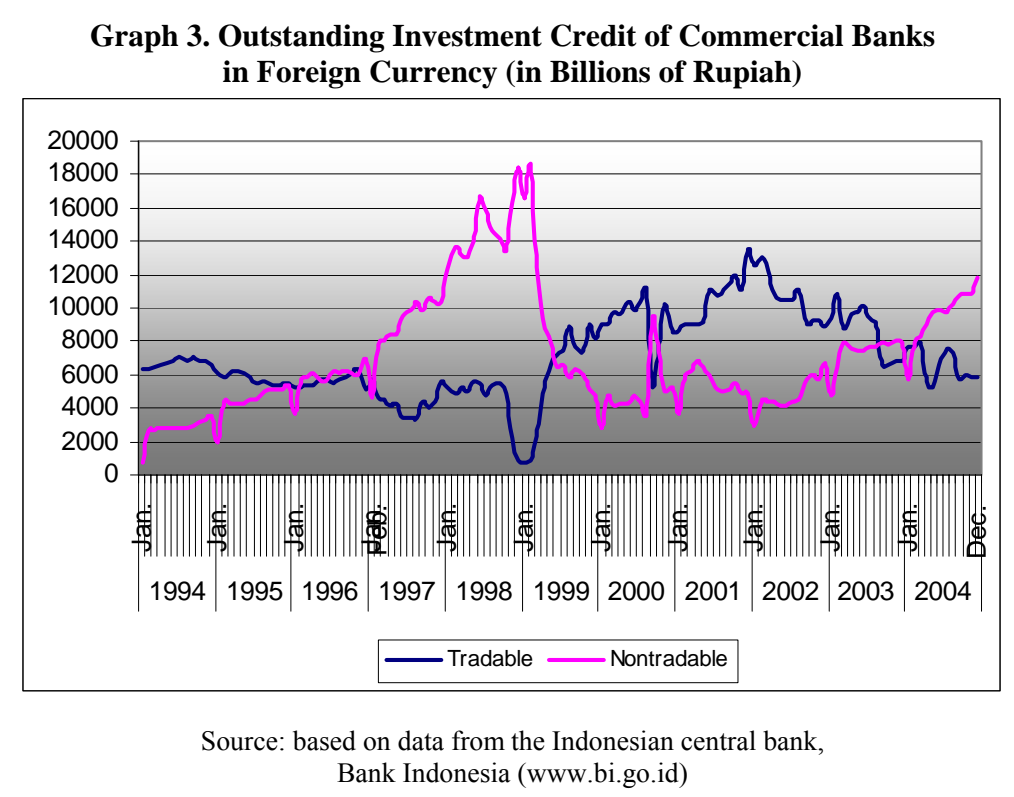

Based upon the data showing the outstanding investment credit of commercial banks in both domestic and foreign currencies, we can formulate the second stylized fact as follows:

Stylized fact 2. It is likely that the balance sheets of non-tradable sector firms contain much more foreign debt than those of tradable sector firms, and therefore the impact of exchange rate depreciations had a more serious impact on the $N$-sector than on the T-sector.

Following a currency depreciation accompanied by tight money policies, firms prefer not to access credit from the banking sector, and the banking sector tends to be reluctant to supply credit to the corporate sector so as to avoid the risk of unpaid debts. In a study conducted by Bank Indonesia, it was confirmed that credit crunch is present following financial crises in Indonesia. ${ }^{7}$ The banking sector preferred not to offer their credit to the firms sector to avoid the default risk.

${ }^{7}$ Bank Indonesia has conducted research on the presence of credit crunch following the financial crisis in Indonesia. For further information, the results of the study may be found in www.bi.go.id : "Credit Crunch In Indonesia in the Aftermath of the Crisis: Facts, Causes and Policy Implications" Working Paper, 2000, Directorate of Economic Research and Monetary Policy Bank Indonesia, prepared by Agung Juda, Bambang Kusmiarso, Bambang Pramono, Erwin G. Hutapea, Andry Prasmuko, and Nugroho Joko Prastowo. 
Theoretically, the lack of credit supply to the firms sector could have a second-round effect on business failures, which could also exacerbate the quality of bank loans. Under such conditions, there is a risk that the collapsing real sector could give rise to the banking crisis in the second round. Hence, there exists a complicated vicious circle which cannot easily be resolved.

The soaring of interest rates following a sharp depreciation of the exchange rate in 1997 caused firms' debt-equity ratio to increase. High interest rates are detrimental to firms' balance sheets. This means that a hike in interest rates directly influences a firm's corporate value, or net worth. Moreover, firms undergoing weak financial conditions tend first to carry out financial consolidation, rather than conducting business expansion. Meanwhile, firms with a bad balance sheet cannot pay their maturity debt to the bank. At this point, the deterioration of the firm's net worth has a direct correlation with the banking sector's balance sheet.

Following a financial crisis, firms usually prefer to reduce their activities by postponing their loans from the banking sector. Instead of expansion, firms prefer to consolidate their internal activities in operation by reducing their internal liquidity and inventories, rather than by borrowing from a bank. In this case, the demand for workingcapital credit decreases significantly. Added to the uncertainties in economic and business conditions due to the financial crisis, firms prefer to use their own capital rather than to borrow from a bank at high interest rates.

Bank Indonesia's study also finds that firms preferred to use their own funds (retained earnings) as their main source of finance in the aftermath of the crisis. ${ }^{8}$ Retained earnings were used by $56 \%$ of respondents to this survey, while $44 \%$ used external funds, the majority of which (24\%, comprising 14\% working capital credit and 10\% investment credit) still originated from bank credit. Other sources of external financing were the capital market $(6 \%)$, offshore loans $(5 \%)$, bonds $(3 \%)$, and from their own group $(1 \%){ }^{9}$

The balance-sheet-effect mechanism simultaneously attacks both the firms and banking sectors. This mechanism commonly occurs in countries with weak corporate and banking sectors, where third-generation crisis is present. In Mexico, a crisis reduced GDP in the last three quarters of 1995 from $9.2 \%$ to $-8 \%$ and then to $7 \%$, respectively. However,

\footnotetext{
${ }^{8}$ Despite the reluctance of the banking sector to offer credit to the firms sector, Bank Indonesia's survey of 120 firms concerning their financing behavior following the financial crisis in Indonesia also confirms that the firms sector is reluctant to access credit from the banking sector.

${ }^{9}$ See Juda Agung et al. (2000).
} 
Mexico was more fortunate than Indonesia since there was an immediate recovery in economic conditions. Between the second quarter of 1996 and the first quarter of 1998, GDP growth increased on average by more than $5 \% .^{10}$

In Mexico, asymmetric financing constraints were also present, in which, in the postcrisis period, the tradable sector grew and recovered easily, whereas the non-tradable sector faced stagnation and credit crunch. Some studies predict that the tradable sector is usually able to obtain funding from the international market, while the non-tradable sector must depend on its own finance because banks are reluctant to provide credit. ${ }^{11}$

Stylized fact 3. Financial constraints on firms prolonged the crisis into the long-term and therefore heightened the risk of a banking crisis, since credit could not be channeled into the real sector.

Until the end of 2006, the bulk of liquidity was not channeled to real sector. Bank Indonesia (2007) states that: "Meanwhile, the domestic economy remained relatively steady supported by monetary stability. Unfortunately, such conditions were not fully utilised to foster economic growth, primarily because of inefficiency as well as an unfavourable business climate and restricted real sector growth." ${ }^{2}$ Firms' internal problems are coupled with external structural problems in the economy following a deep crisis.

\section{Theoretical Overview: Credit Market Frictions}

\subsection{The Financing Constraint Paradigm}

Theoretically, monetary authority is generally able to affect the corporate sector through multiple channels. Bernanke and Gertler (1995) differentiate the 'balance sheet channel' from the 'bank lending channel.' The balance sheet channel focuses on the impact of monetary policy on the borrower's balance sheet through the firm's net worth, cash flow, and liquid assets. Meanwhile, the bank lending channel reveals the role of monetary policy through changes in loan supply as effected by banking institutions.

Hubbard (1998) makes a distinction between the 'money view' and 'credit view' to understand the channels though which monetary policy affects economic variables. The credit

\footnotetext{
${ }^{10}$ Comparisons with neighboring countries in East Asia and Latin America is also addressed in the study by Juda Agung et al. (2000)

11 This issue is still debatable. Espanol (2005), for example, provides empirical evidence that, following a financial crisis in Argentina, the tradable sector was more financially constrained than the non-tradable sector.

${ }^{12}$ Bank Indonesia, Financial Stability Review II - 2006, No.8 March 2007.
} 
view considers the financial accelerator (Bernanke, Gertler and Gilchrist 1998) to consist of the magnification of initial shocks by financial market conditions. This argument is based on the problems of asymmetric information between borrowers and lenders creating a gap between the cost of external and internal financing.

Azis (2004) argues that the ineffectiveness of monetary policy can be closely associated with the problem of credit allocation. Furthermore, unlike in traditional monetary economics, the basic premises underpinning the new monetary economic are: (1) credit, not interest rates, plays the central role in determining economic activities; (2) the presence of asymmetric information implies that there is a cost for acquiring information (agency cost) and that this cost is sunk; (3) the relation between money and output is not necessarily stable.

Recent developments in monetary and finance theory take into account the informational and incentive problem in financial markets influencing capital-structure and investment decisions. This premise is referred to as the 'financing constraint paradigm,' which explains how market imperfections and corporate balance-sheet conditions correlate with firm-level investment.

Jensen and Meckling (1976) and Myers and Majluf (1984) are the founding fathers of the financing constraint paradigm. Jensen and Mecking demonstrate that incentive or agency problems raise the cost of external finance. Agency problems emerge when managers control the firm without owning it. Meanwhile, Myers and Majluf concern themselves with information problems, arguing that if managers are better informed than investors about a firm's prospects, the firm's risky securities will sometimes be under-priced. In this case, the cost of external finance should be raised.

The main concern of this paper is to examine how liquidity, or the availability of internal funds, determines investment when there are information problems in the capital market. Many studies have documented a positive relationship between liquidity and investment (Fazzari, Hubbard, and Peterson 1988; Hoshi, Kashyap, and Scharfstein, 1991; Chirinko and Schaller, 1996; Chirinko and Kalckreuth, 2002; Bruinshoofd, 2003; Mizen and Vermeulen, 2005;). In these studies, cash flow or cash stock usually stand as a proxy for liquidity, while investment is measured by capital expenditures deflated by capital stock. The sensitivity relation between investment and internal liquidity is referred to as a degree-offinancing constraint. 
Fazzari et al. (1988) claims that the sensitivity of investment to increases in internal funds is driven by financing constraints resulting from informational problems in the capital market. This argument is known as the financing constraint paradigm. Fazzari et al. also show that investment-cash-flow sensitivities are greater for firms with low dividend payout ratios. This greater sensitivity means higher financial constraints. Bruinshoofd (2003) supports the joint hypothesis that constrained firms can be identified and display a stronger sensitivity of investment to cash flow.

However, the use of investment-cash-flow sensitivity has received some important criticism. Kaplan and Zingales (1997) question the financing constraint paradigm by arguing that investment-cash-flow sensitivity is not a useful indicator of financing constraints, as it is not necessarily related monotonically to the cost of external finance or to the level of internal funds available. Therefore, Kaplan and Zingales (1997) propose discarding the use of investment-cash-flow sensitivities in the empirical analysis of financing constraints.

Some studies, on the other hand, have employed this approach based on investmentcash-flow sensitivity. Géczy, Minton and Schrand (1997) documented that firms with higher levels of cash-flow volatility have lower capital expenditure, research and development costs, and advertising expenses. According to this study, one explanation for this relation is that different levels of investment produce different volatilities, depending on the nature of the investment. Firms commonly do not use external debt and equity markets to smooth cash flow volatility, because the costs of accessing capital markets also are related to the volatility of a firm's cash flow.

Overall, there are several valid reasons to support the argument that internal liquidity is significantly related to investment. Chirinko and Schaller (1996) describe two reasons why liquidity matters in investment equations. One is that firms face financial constraints that drive a wedge between the costs of internal and external finance. The second explanation is that liquidity serves as a proxy for omitted variables and other specification problems.

\subsection{Boom-Bust Cycles}

Under the financing constraint paradigm, one of the most important sources of financial fragility is linked to credit market imperfections. Credit market imperfections in developing countries entail three important problems, namely, the existence of borrowing constraints, currency mismatch, and systemic bailout guarantees (Tornell and Westermann, 
2003). This is the reason why countries that have liberalized their financial system tend to experience a greater risk of crises. Financial liberalization is usually followed by risky international bank flows and lending booms. Tornell and Westermann explain that such imperfections in credit markets mean that financial liberalization in middle-income countries has typically been followed by lending booms, ending with twin currency and banking crises that, in turn, result in a protracted credit crunch.

It is a trade-off between high growth and an elevated risk of crises, since factors that contribute to financial fragility are also a source of growth. In this case, credit markets play a key role in such large fluctuations, not only in the boom-bust episodes that surround crises, but also in the strong 'credit channel' observed in tranquil times, that is, the strong response of GDP and other macroeconomic variables to credit market shocks (Tornell and Westermann, 2004).

Credit channels play an important role in economic fluctuation by influencing sectoral economics, especially in dissociating the tradable $(\mathrm{T})$ and non-tradable $(\mathrm{N})$ sectors of the economy. In tranquil times, asymmetry in financing opportunities can cause asymmetric sectoral development between the T-and N-sectors, in which the N-sector grows faster than T-sector. For several years following a crisis, the N-sector's output would then decline relative to that of the $\mathrm{T}$-sector.

In a liberal financial system, the asymmetry in financing opportunities across the $\mathrm{T}$ and N-sectors may be accompanied a currency mismatch in credit, in which a substantial amount of N-sector debt is dollar denominated, while its income remains in domestic currency. In developing countries, the government plays an important role in protecting corporate borrowing through systematic guarantees. Then this policies are usually followed by an imprudent and un-hedging behavior on corporate borrowing in both the banking and corporate sectors.

Accordingly, these three factors, namely, asymmetry in financing opportunities, government guarantees, and currency mismatches, can, acting in combination, be extremely dangerous and result in a financial crisis. This fundamental fragility could then easily be exacerbated by panic behavior or self-fulfilling actions by investors, since the government's systematic guarantees are commonly accompanied by enforceability problems which can, in turn, generate self-reinforcing mechanisms. Tornell and Westermann (2002a) describe the mechanism as follows. If many $\mathrm{N}$-sector agents gamble by denominating their debt in foreign 
currency, exchange rate risk may be created endogenously, as the economy becomes vulnerable to self-fulfilling mechanisms in the banking system. Usually, N-sector firms face severe contract enforceability problems and their lenders enjoy systematic bailout guarantees - in the event of crises, lenders are bailed out at the taxpayers' expense (Tornell and Westermann 2004).

Furthermore, Tornell and Westermann also explain that contract enforceability problems, together with bailout guarantees, may easily generate stringent financing constraints and lead borrowers to take on credit risk in the form of currency mismatch. In such a case, the shocks to firms' cash flow have a strong effect on the economy. This mechanism is referred to as a 'balance sheet effect mechanism'.

Credit market imperfections have caused boom-bust cycles in credit, in which financing opportunities across the $\mathrm{T}$ - and $\mathrm{N}$-sectors become asymmetric, the process being followed by economic vulnerability. It is therefore evident that asymmetric financing opportunities are vital in understanding financial fragility and economic vulnerability in developing countries, where credit market friction is common.

\section{Empirical Research}

To deal with the question of which sector, $\mathrm{T}$ or $\mathrm{N}$, performs better in the pre- and postcrisis periods, this paper employs a relatively rigorous equation to measure the sensitivity of firm-level investment and its liquidity. Put simply, this study intends to examine the boombust cycle by employing the financing constraint paradigm.

\subsection{Investment equation}

Since the 1988 seminal paper by Fazzari, Hubbard, and Petersen (FHP), the issue of financing constraints and firms' investment have been debated in the literature. ${ }^{13}$ FHP show that firms identified as, a priori, financially constrained should exhibit greater sensitivity in investment and the availability of internal finance in terms of cash flow. In their hypothesis on the financing constraint paradigm, they claim that the sensitivity of investment and liquidity is driven by the presence of asymmetric information in the capital market.

\footnotetext{
${ }^{13}$ Differing from MM, FHP assume that external finance is more expensive since asymmetric information is present.
} 
This argument differs substantially from the neoclassical perspective on investment, as expressed by Modigliani and Miller (MM; 1958), who advocate the irrelevance of financial structure theory, by explaining that financial policy is separate from real investment decisions under certain conditions. ${ }^{14}$ Conversely, FHP propose theoretical models of the imperfections in the capital market, which imply that external financing is more costly than internal financing for many firms. Since the degree of asymmetric information and agency costs depends on a firm's characteristics, certain firms may be more sensitive to financial factors than others. In other words, industrial or individual characteristics of firms become important determinants of their investment sensitivity to internal finance (cash flow).

Under FHP's argument, investment should be significantly related by proxy to changes in a firm's net worth or internal funds. As do many previous studies, this paper uses the ratio of cash flow to capital stock $(\mathrm{CF} / \mathrm{K})$ as the internal financing condition of firms. A large body of research has found that the sensitivity between investment and cash flow are higher for financially constrained firms (FHP, 1998; Chirinko and Kalckreuth, 2002).

To provide empirical evidence, this paper uses the basic equation originally developed by FHP (1988) as follows:

$I=f($ investment opportunities $)+g($ internal funds)

Or,

$$
\frac{I_{i t}}{K_{i t-1}}=f\left(\frac{X_{i t}}{K_{i t-1}}\right)+g\left(\frac{C F_{i t}}{K_{i t-1}}\right)+\varepsilon_{i t}
$$

Where $I_{i t}$ represents investment in fixed assets for firm $i$ during period $t, X$ represents a vector of variables, and $\varepsilon$ is the error in $i$ and $t$.

Following FHP (1988), the function $g$ depends on the firm's internal cash flow $(C F)$, which represents the potential sensitivity of investment to fluctuations in available internal

\footnotetext{
${ }^{14}$ In their seminal paper, "Theory of Capital Structure", published in 1958, MM argue that firms' financial structure will not affect their market value in a frictionless capital market. They assume that information is perfect in the capital market.
} 
finance, after investment opportunities are accounted for through the variables in $X$. All variables are divided by the capital stock at the beginning of the period $\left(K_{t-1}\right)$.

The sensitivity of internal capital and investment is commonly analyzed by dividing samples depending on firms' characteristics; for example, firms are categorized according to their (low or high) dividend payout rate (Fazzari et al., 1998), status as Keiretsu or independent firms (Hoshi et al., 1991), bond rating (Whited, 1992), and whether they belong to the tradable or non-tradable sector (Espanol, 2005). As the interest of this research resides in the asymmetry of sectoral development, this paper runs regression for two categories of firm, classifying them as tradable (T) and non-tradable $(\mathrm{N})$ sector firms. Fixed assets are used as a proxy for long-term investment. For capturing the sensitivity of the $\mathrm{T}$ - and $\mathrm{N}$-sectors, this paper employs the following equation:

$$
\frac{I_{i t}}{K_{i t-1}}=\alpha_{c f t}\left(\frac{C F_{i t}}{K_{i t-1}}\right) * T+\alpha_{c f n}\left(\frac{C F_{i t}}{K_{i t-1}}\right) * N+\alpha_{q} Q_{i t}+\alpha_{s}\left(\frac{T S_{i t}}{K_{i t-1}}\right)+\alpha_{w k}\left(\frac{W C_{i t}}{K_{i t-1}}\right)+\alpha_{d}\left(\frac{T D_{i t}}{K_{i t-1}}\right)+\varepsilon_{i t}
$$

\section{Where}

$\begin{array}{lll}\mathrm{K} & = & \text { fixed assets } \\ \mathrm{I} & = & \text { long-term, or gross, investment }\left(\mathrm{K}_{\mathrm{t}}-\mathrm{K}_{\mathrm{t}-1}\right) \\ \mathrm{CF} & = & \text { cash flow } \\ \mathrm{Q} & = & \text { Tobin's } \mathrm{Q} \\ \mathrm{TS} & = & \text { total sales } \\ \mathrm{WC} & = & \text { working capital (current assets }- \text { current liabilities) } \\ \mathrm{TD} & = & \text { total debt } \\ \mathrm{T} & = & \text { tradable sector } \\ \mathrm{N} & = & \text { non-tradable sector }\end{array}$

We are also concerned with the industrial-sector effects. To achieve this, this paper uses an equation in which dummies for different industrial sectors are introduced. This allows us to focus on the effect of its industrial sector on the relation between a firm's investment and liquidity. For this purpose, this paper does not split the sample into two different groups as was done for equations (2). We employ equation as follows with dummies for each sector. 
(3)

$$
\frac{I_{i t}}{K_{i t-1}}=\alpha_{c f}\left(\frac{C F_{i t}}{K_{i t-1}}\right)+\alpha_{q} Q_{i t}+\alpha_{s}\left(\frac{T S_{i t}}{K_{i t-1}}\right)+\alpha_{w k}\left(\frac{W C_{i t}}{K_{i t-1}}\right)+\alpha_{d}\left(\frac{T D_{i t}}{K_{i t-1}}\right)+\varepsilon_{i t}
$$

Industrial sector dummies ${ }^{15}$

1. Sector A (basic industry): agriculture (sector 1), mining (sector 2).

2. Sector B (manufacturing): basic industry and chemical industries (sector 3), miscellaneous industry (sector 4), consumer goods industry (sector 5).

3. Sector C (services): property, real estate, and building construction (sector 6), infrastructure, utilities, and transportation (sector 7), trade, service, and investment (sector 9$).^{16}$

\subsection{Variables}

\subsubsection{Investment}

Firm-level investment is commonly understood as the value of machinery, plant, and buildings that are bought by firms for production purposes. Accordingly, this paper uses fixed assets as proxy for investment over long-term periods. Theoretical predictions consider that constrained firms should display a stronger sensitivity of investment to cash flow (FHP, 1998; Chirinko and Kalckreuth, 2002; Bruinshoofd, 2003). In this case, if the N-sector faces greater financial constraints than the T-sector, $\boldsymbol{\alpha}_{c f N}$ would be expected to be higher than $\boldsymbol{\alpha}_{c f T}$.

\subsubsection{Cash-Flow}

In Fazzari, Ferri and Greenberg (2003), we find that in the Keynesian endogenous investment model, if cash flow is insufficient to finance investment, firms take on debt. The implication is that investment activities should be financed primarily by internal finance before accessing external sources. In this case, cash flow would generally be negatively related to firm investment.

Recently, a large body of literature has suggested that, due to information asymmetries and capital market imperfections, corporate investment expenditure is significantly influenced

\footnotetext{
${ }^{15}$ For sector dummies we use the JASICA or sectoral index classification which was released by the Jakarta Stock Exchange Authority in January 1996.

${ }^{16}$ We exclude the financial sector (sector 8 ) since the financial statements of this sector are substantially different from those of industries in other sectors.
} 
by firms' ability to generate internal cash. This leads to the explanation that firms prefer internal equity to external debt, with the result that investment should be related negatively to debt.

\subsubsection{Tobin's $Q$}

Tobin's $\mathrm{Q}$ is associated with a firm's market capitalization, reflecting the market anticipations of investment opportunities in firm profitability. Tobin's Q is measured by the market value of assets deflated by their book value. In this paper, $\boldsymbol{\alpha}_{\boldsymbol{q}}$ is expected to be significant and positive.

\subsubsection{Profitability}

In this paper, sales in period previous to that probed are used as a proxy for profitability. By common sense, profitability increases with investment. We expect that profitability will be significant and positive. Profitability is considered to explain the past and potential future performance of a firm. It is consistent with the sales accelerator model; higher sales levels will enhance production capacity in order that enlarged demand may be met (FHP, 1988).

\subsubsection{Working Capital}

Fazzari and Petersen (1993) describe working capital as composed of current assets (chiefly, accounts receivable, inventories, and cash) less current liabilities (primarily, accounts payable and short-term debt), and as measuring the firm's net position in liquid assets. Fazzari and Petersen (1993) argue that, due to financial constraints, it is costly for firms to change their level of fixed investment, and thus they seek to maintain a stable fixedinvestment path, over commensurate options requiring working capital adjustments. This argument is comparable to the internal net works hypothesis (Bernanke and Gertler, 1986).

External finance, if available, may be more costly than internal finance because of transaction costs, agency problems, and asymmetric information. Thus, ceteris paribus, when firms choose to decrease (increase) their working capital investment, fixed investment levels should rise (fall) correspondingly.

In this case, $\boldsymbol{\alpha}_{\boldsymbol{w}}$ is expected to be significant and negative. 


\subsubsection{Debt}

There are two opposite theoretical approaches treating the relationship between a firm's leverage and its cash flow. Trade-off theory suggests a positive relationship (Modigliani and Miller, 1958), while pecking order behavior implies a negative relationship (Myers and Majluf, 1984). Meanwhile, signaling theory suggests that a higher debt ratio can be considered as a signal of an improved capacity to finance investment, hence yielding a positive relationship between debt and investment.

\section{Results}

\subsection{Data set and Univariate Analysis}

This study is composed of all non-financial firms listed on the Jakarta Stock Exchange (JSX), and based on yearly accounting data provided by JSX's database and the Indonesian Capital Market Directory (ICMD) maintained by ECFIN, a private company. We have 298 samples, comprising all non-financial firms listed at different time periods. Neither database contains cash flow variables. Accordingly, we directly accessed each firm's annual report, as documented on the JSX. In this case, we manually input data.

We retain only data covering at least five consecutive years. Furthermore, we exclude outliers by sorting data based upon its standard deviation, removing data with more than 10.00 standard deviations. This leaves 147 firms over the period 1994-2004. For classification of the T- and N-sectors, this research follows that used by the JSX.

To examine the different investment levels between the $\mathrm{T}$ - and $\mathrm{N}$-sectors, this paper employs two tests of variance, which are the t-test for mean variance (t-statistic) and the Wilcoxon rank-sum (Mann-Whitney) test for median variance (z-statistic). It is clear from Table (1) that there is no significant difference in firm-level investment between the two sectors. But there is significant difference on inventory, in which $\mathrm{T}$ sector has much more inventory than $\mathrm{N}$ sector. Others important differences are that $\mathrm{T}$ sector has much more total sales and working capital, with high significant differences in both mean and median variances, whereas tradable sector's total debts are much less than those of $\mathrm{N}$ sector. 


\begin{tabular}{|c|c|c|c|c|c|c|c|c|c|}
\hline & Mean & Median & Stan Dev & Max & Min & t-test & p-value & z-test & p-value \\
\hline \multicolumn{10}{|l|}{ Investment over capital stock } \\
\hline All & 0,08747 & $-0,05847$ & 0,66528 & 9,39441 & $-0,93234$ & -0.0899 & 0.9284 & 0.183 & 0.8552 \\
\hline T sector & 0,08842 & $-0,06281$ & 0,67803 & 9,39441 & $-0,91596$ & & & & \\
\hline N sector & 0,08477 & $-0,04775$ & 0,62866 & 5,38558 & $-0,93234$ & & & & \\
\hline \multicolumn{10}{|l|}{ Inventory over capital stock } \\
\hline All & $-0,00416$ & $-0,00006$ & 0,26979 & 2,78275 & $-3,85270$ & -2.8215 & 0.0048 & -2.451 & 0.0142 \\
\hline T sector & 0,00791 & 0,00121 & 0,19359 & 1,20020 & $-1,36137$ & & & & \\
\hline N sector & $-0,03833$ & $-0,00040$ & 0,41425 & 2,78275 & $-3,85270$ & & & & \\
\hline \multicolumn{10}{|l|}{ Cash flow over capital stock } \\
\hline All & 0,03608 & 0,00250 & 0,35521 & 7,84430 & $-1,95120$ & -1.0116 & 0.3119 & $\begin{array}{l}-0.996 \\
\end{array}$ & 0.3193 \\
\hline T sector & 0,04196 & 0,00340 & 0,37717 & 7,84430 & $-1,95120$ & & & & \\
\hline N sector & 0,01988 & 0,00044 & 0,28602 & 2,11622 & $-1,36923$ & & & & \\
\hline \multicolumn{10}{|l|}{ Tobin's $Q$} \\
\hline All & 1,13500 & 1,00620 & 0,55820 & 6,58397 & $-0,95640$ & -1.6526 & 0.0986 & -0.273 & 0.7846 \\
\hline T sector & 1,14983 & 1,01269 & 0,58757 & 6,58397 & 0,32254 & & & & \\
\hline N sector & 1,09319 & 0,99041 & 0,46376 & 4,48206 & $-0,95640$ & & & & \\
\hline \multicolumn{10}{|l|}{ Total sales over capital stock } \\
\hline All & 1,92275 & 1,20791 & 1,83441 & 9,97830 & 0,01435 & -5.0959 & 0.0000 & -8.607 & 0.0000 \\
\hline T sector & 2,06993 & 1,41080 & 1,81042 & 9,97830 & 0,01435 & & & & \\
\hline N sector & 1,50580 & 0,69680 & 1,84028 & 8,53232 & 0,03524 & & & & \\
\hline \multicolumn{10}{|l|}{ Working capital over capital stock } \\
\hline All & 0,23517 & 0,16262 & 1,25500 & 7,96675 & $-8,25325$ & -3.6612 & 0.0003 & -3.798 & 0.0001 \\
\hline T sector & 0,30783 & 0,20161 & 1,30662 & 7,96675 & $-8,25325$ & & & & \\
\hline N sector & 0,02932 & 0,05957 & 1,07077 & 3,82783 & $-5,03821$ & & & & \\
\hline \multicolumn{10}{|l|}{ Total debt over capital stock } \\
\hline All & 1,68833 & 1,34431 & 1,23987 & 8,70960 & 0,10730 & 6.0999 & 0.0000 & 4.127 & 0.0000 \\
\hline T sector & 1,56972 & 1,31962 & 1,10129 & 8,70960 & 0,11598 & & & & \\
\hline $\mathrm{N}$ sector & 2,02434 & 1,47720 & 1,51957 & 7,34419 & 0,10730 & & & & \\
\hline
\end{tabular}


In Graph 4, we can see how investment in both the tradable and non-tradable sectors fell during the crisis. ${ }^{17}$ We can also remark that at the onset of crisis (1995-1996), in both the $\mathrm{T}$ - and $\mathrm{N}$-sectors, the investment rate tends to diminish. From this graph, it seems that there is no significant difference between the investment levels of firms belonging to the tradable and non-tradable sectors; they change comparably.

Graph 4. Mean of Firm-level Investment over Capital Stock ( $\left.\frac{I_{i t}}{K_{i t-1}}\right)$

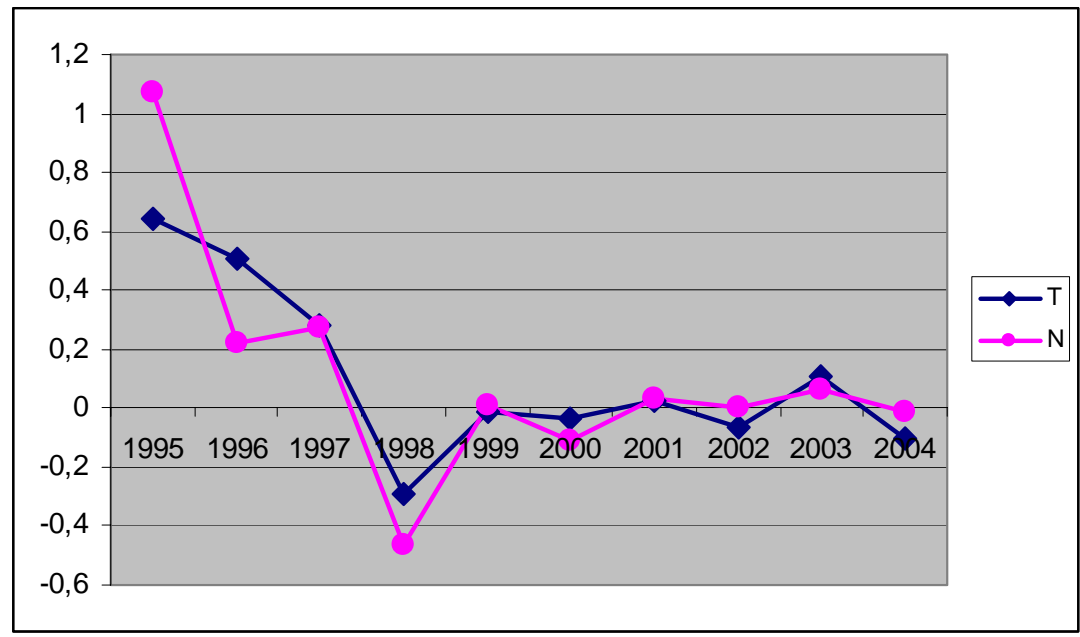

Source: author's calculation based on JSX's database and the Indonesian Capital Market Directory provided by ECFIN. Note: $\mathrm{T}$ is the tradable sector, $\mathrm{N}$ is the non-tradable sector.

In Graph 5, we can see that the mean of inventory for $\mathrm{N}$ sector is more severely affected by exchange rate depreciation than that of $\mathrm{T}$ sector. However, since 2003 their trends are comparable.

${ }^{17}$ This study uses time lag variables as the deflator, which is gross capital. Consequently, the time covered by the study is lessened by one period due to the absence of a deflator for last period (1994). 
Graph 5. Mean of Inventory change over Capital Stock $\left(\frac{\Delta \text { Inventory }_{i t}}{K_{i t-1}}\right)$

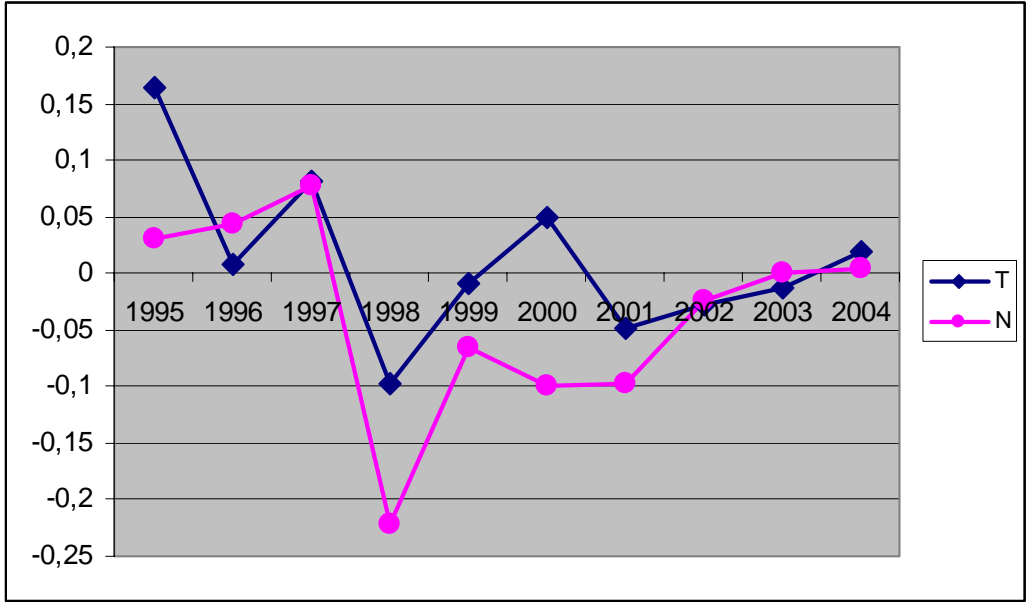

Source: author's calculation based on JSX's database and the Indonesian Capital Market Directory provided by ECFIN. Note: $\mathrm{T}$ is the tradable sector, $\mathrm{N}$ is the non-tradable sector.

In terms of cash flow volatility, or firm liquidity, as is described in Graph 6, it seems that sector $\mathrm{N}$ fluctuates more severely than sector T. But the recent year (it mean 2004), the cash flow of $\mathrm{N}$ sector is higher than that of $\mathrm{T}$ sector.

Graph 6. Mean of Cash Flow over Capital Stock $\left(\frac{C F_{i t}}{K_{i t-1}}\right)$

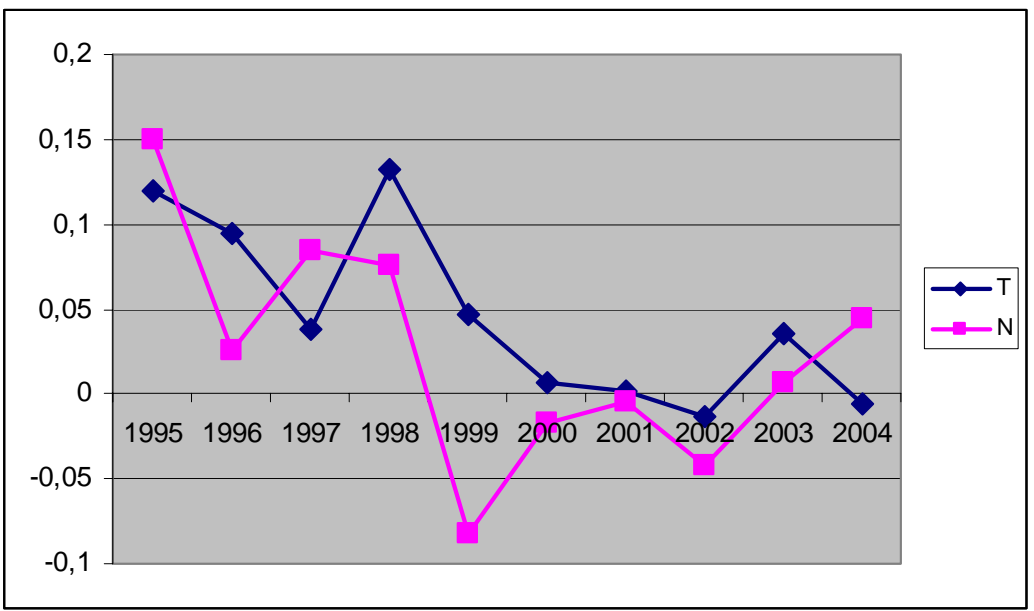

Source: author's calculation based on JSX's database and the Indonesian Capital Market Directory provided by ECFIN.

Note: $\mathrm{T}$ is the tradable sector, $\mathrm{N}$ is the non-tradable sector.

It seems that Tobin's Q, as a proxy for firms' value, does not differ significantly between the sectors. By graphical observation, Graph 7 shows a slight difference in Tobin's Q 
between the two sectors; however, from the tests of variance, it is evident that there is no significant difference in Tobin's Q. The test for differences in the median demonstrates the insignificance difference between the $\mathrm{T}$ - and $\mathrm{N}$-sectors. But t-test shows significant difference in which Tobin's Q of T sector is slightly higher than that of $\mathrm{N}$ sector.

\section{Graph 7. Mean of Tobin $Q$}

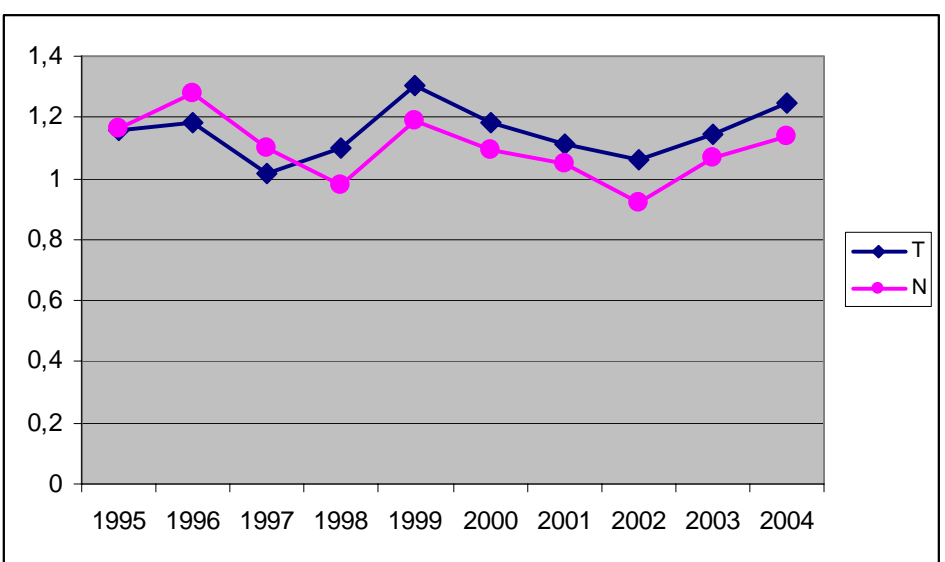

Source: author's calculation based on JSX's database and the Indonesian Capital Market Directory provided by ECFIN. Note: $\mathrm{T}$ is the tradable sector, $\mathrm{N}$ is the non-tradable sector.

From the following graph (Graph 8), it seems that the T-sector has a much higher level of sales than the $\mathrm{N}$-sector. Test of variance also shows a significant difference at the one percent level for the t-statistic and z-statistic. The differences are important; the mean difference is 5.095 and the median difference is 8.607 , both with one percent level of significance. 
Graph 8. Mean of Total Sales over Capital Stock $\left(\frac{T S_{i t}}{K_{i t-1}}\right)$

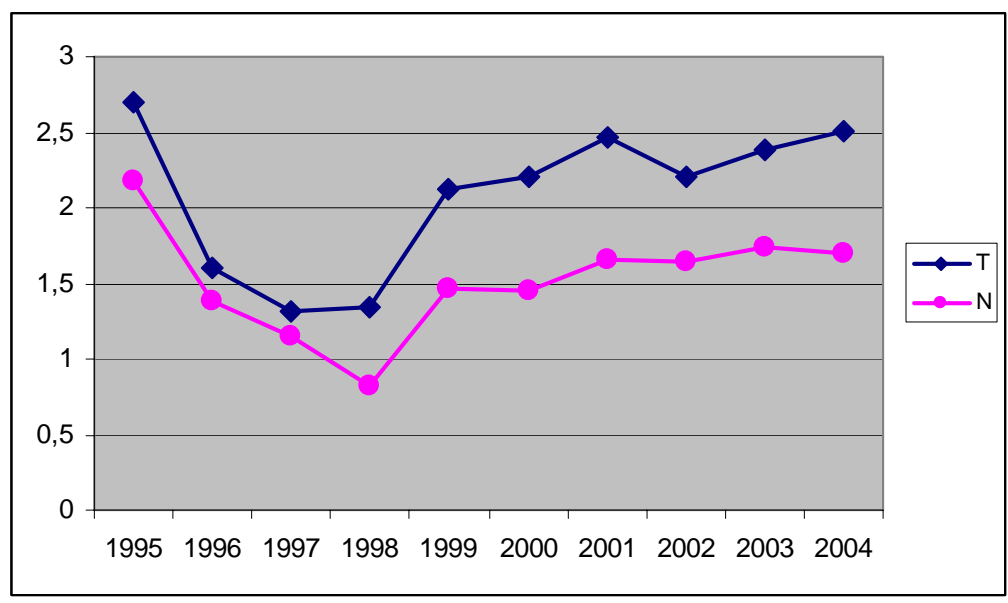

Source: author's calculation based on JSX's database and the Indonesian Capital Market Directory provided by ECFIN.

Note: $\mathrm{T}$ is the tradable sector, $\mathrm{N}$ is the non-tradable sector.

In terms of working capital, Graph 9 shows that the $\mathrm{T}$ - and N-sectors also have important difference where $\mathrm{T}$ sector is much higher than $\mathrm{N}$ sector following a financial crisis.

Graph 9. Mean of Working Capital over Capital Stock $\left(\frac{\Delta W K_{i t}}{K_{i t-1}}\right)$

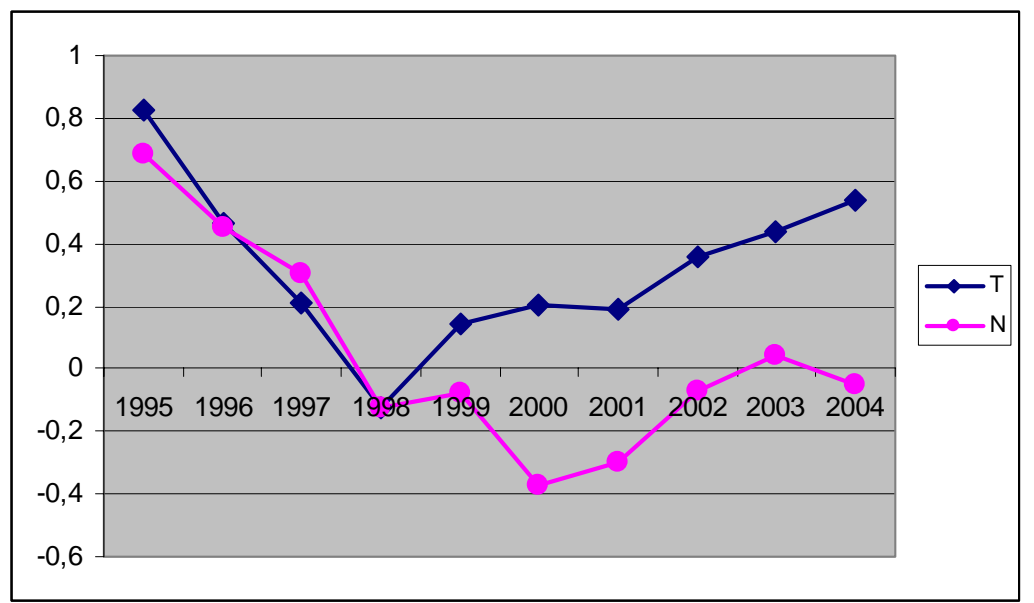

Source: author's calculation based on JSX's database and the Indonesian Capital Market Directory provided by ECFIN. Note: $\mathrm{T}$ is the tradable sector, $\mathrm{N}$ is the non-tradable sector.

In terms of debt, $\mathrm{N}$-sector levels are much higher than those of the T-sector. Previous studies found that the $\mathrm{N}$-sector in South East Asian countries plays an important role in propagating financial crisis, because it mostly gains revenue in local currencies, while holding 
leverage in foreign currencies. The $\mathrm{N}$-sector has a higher debt ratio than the $\mathrm{T}$-sector. This evidence is supported by the t-statistic (6.099) and z-statistic (4.127). Both tests are significant at the one percent level.

Graph 10. Mean of Total Debt over Capital Stock $\left(\frac{D_{i t}}{K_{i t-1}}\right)$

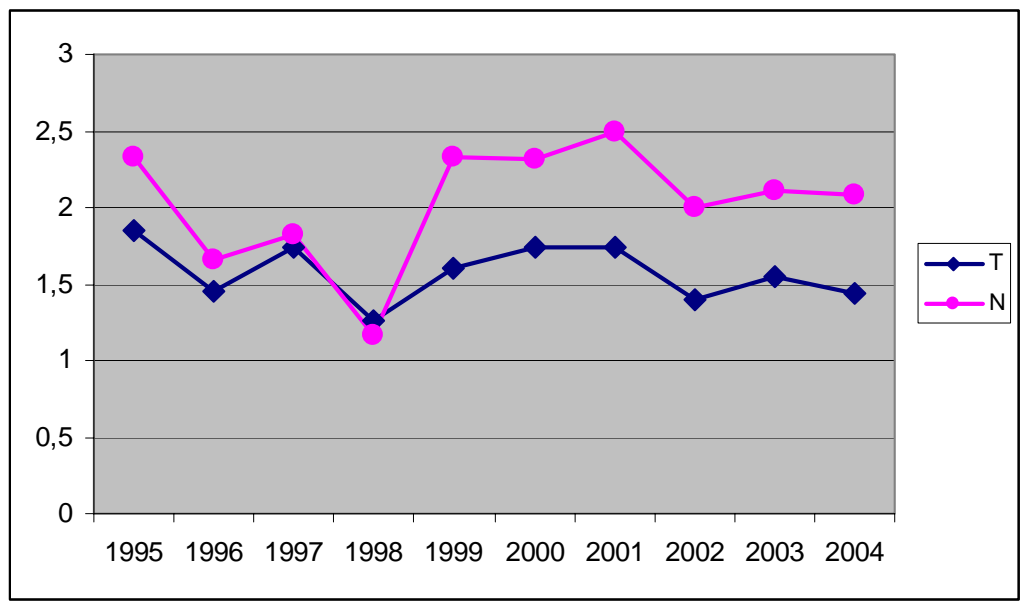

Source: author's calculation based on JSX's database and the Indonesian Capital Market Directory provided by ECFIN. Note: $\mathrm{T}$ is the tradable sector, $\mathrm{N}$ is the non-tradable sector.

During the crisis (1997-1998), firms had a higher rate of debt due to currency depreciation than in the pre-crisis period. Data from Bank Indonesia (Graphs 1, 2, and 3) shows that outstanding investment credit increased during the crisis period even though interest rates were also boosted. It seems that most firms failed to reschedule their debts, and to avoid the risk of bankruptcy, they had to access external finance.

Many firms collapsed. Firms experiencing great difficulties in paying their debt were taken over by the Indonesian Banking Restructuring Agency (IBRA), whose main task is to restructure the banking sector by taking over firms with bad debts.

However, both sectors differ significantly in regard to profitability and debt level. Over the full period (1994-2005), the N-sector had much higher levels of debt. In terms of profitability, the $\mathrm{N}$-sector has higher profitability than the T-sector. 


\subsection{Multivariate Analysis}

\subsubsection{Tradable and Non-tradable Sector Analysis}

This research uses two methods of panel data analysis, namely fixed-effect and random-effect models. The random-coefficient model assumes that, conditional on companyspecific effects, remaining slope coefficients are randomly distributed about a certain mean for each group (Hsiao and Tahmiscioglu 1997).

Concerning the main goal of this paper, we follow Fazzari, Hubbard and Petersen (1988), who predict that the higher coefficient of correlation between cash flow and investment represents firms having greater financial constraints. Table 2 demonstrates the regression results for investment. We find that over the full period (1994-2004), the nontradable $(\mathrm{N})$ sector and the tradable $(\mathrm{T})$ sector have no significant coefficient of correlation between cash flow and investment. It seems that for both sectors, the internal finance is not important variable affecting the investment level.

When we compare the sensitivity relation between cash flow and investment in the pre- and post-crisis periods, we find that in the pre-crisis period, both sectors have negative significant relation between investment and cash flow, whereas in the post-crisis period, both sectors have no significant correlation between internal finance and investment. 


\begin{tabular}{|c|c|c|c|c|c|c|c|c|c|c|c|c|}
\hline 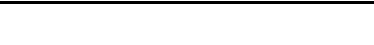 & \multicolumn{4}{|c|}{ Total Period } & \multicolumn{4}{|c|}{ Pre-Crisis } & \multicolumn{4}{|c|}{ Post-Crisis } \\
\hline & \multicolumn{2}{|c|}{$\mathrm{FE}$} & \multicolumn{2}{|l|}{$\mathrm{RE}$} & \multicolumn{2}{|l|}{ FE } & \multicolumn{2}{|l|}{$\mathrm{RE}$} & \multicolumn{2}{|l|}{ FE } & \multicolumn{2}{|l|}{$\mathrm{RE}$} \\
\hline \multirow[t]{2}{*}{ CF over CS for T sector } & $-0,1069$ & & $-0,0969$ & $* *$ & $-0,7285$ & $* * *$ & $-0,3649$ & $* *$ & $-0,0182$ & & $-0,0191$ & \\
\hline & 0,0717 & & 0,0502 & & 0,2392 & & 0,1616 & & 0,0482 & & 0,0459 & \\
\hline \multirow[t]{2}{*}{ CF over CS for N sector } & 0,0676 & & $-0,1107$ & & $-1,5637$ & $* *$ & $-0,1525$ & & $-0,0391$ & & $-0,2787$ & $* *$ \\
\hline & 0,2323 & & 0,1176 & & 0,7182 & & 0,2602 & & 0,1672 & & 0,1263 & \\
\hline \multirow[t]{2}{*}{ Tobin's Q } & $-0,0212$ & & $-0,0160$ & & 0,0644 & & 0,1383 & & $-0,1023$ & $* * *$ & $-0,0892$ & $* * *$ \\
\hline & 0,0430 & & 0,0325 & & 0,2922 & & 0,1072 & & 0,0332 & & 0,0274 & \\
\hline \multirow[t]{2}{*}{ Total Sales over CS } & 0,1216 & $* * *$ & 0,0431 & $* * *$ & 0,0406 & & 0,0794 & $*$ & 0,0851 & $* * *$ & 0,0556 & $* * *$ \\
\hline & 0,0216 & & 0,0129 & & 0,0948 & & 0,0450 & & 0,0192 & & 0,0114 & \\
\hline \multirow[t]{2}{*}{ Working Capital over CS } & 0,0814 & $* * *$ & 0,0799 & $* * *$ & 0,1353 & & $-0,1316$ & $*$ & 0,0518 & $* *$ & 0,0237 & \\
\hline & 0,0239 & & 0,0170 & & 0,1680 & & 0,0699 & & 0,0219 & & 0,0150 & \\
\hline \multirow[t]{2}{*}{ Total Debt over CS } & 0,2735 & $* * *$ & 0,1661 & $* * *$ & 0,8221 & $* * *$ & 0,4143 & $* * *$ & 0,1536 & $* * *$ & 0,0814 & $* * *$ \\
\hline & 0,0264 & & 0,0163 & & 0,1511 & & 0,0583 & & 0,0249 & & 0,0149 & \\
\hline Observation & 1328 & & 1328 & & 212 & & 212 & & 856 & & 856 & \\
\hline R-squared & 0.3139 & & 0.3037 & & 0.6513 & & 0.1687 & & 0.2999 & & 0.0320 & \\
\hline Hausman test & & & 91.97 & & & & 25.65 & & & & 47.46 & \\
\hline p-value & & & 0.0000 & & & & 0.0003 & & & & 0.0000 & \\
\hline Specification & & & FE & & & & FE & & & & FE & \\
\hline
\end{tabular}




\begin{tabular}{|c|c|c|c|c|c|c|c|c|c|c|c|c|}
\hline & \multicolumn{4}{|c|}{ Total Period } & \multicolumn{4}{|c|}{ Pre-Crisis } & \multicolumn{4}{|c|}{ Post-Crisis } \\
\hline & FE & & $\mathrm{RE}$ & & $\mathrm{FE}$ & & $\mathrm{RE}$ & & FE & & $\mathrm{RE}$ & \\
\hline CF over CS for T sector & $-0,2105$ & $* * *$ & $-0,1104$ & $* * *$ & $-0,0806$ & & $-0,0520$ & & $-0,3697$ & $* * *$ & $-0,2930$ & $* * *$ \\
\hline \multirow[t]{2}{*}{ CF over CS for $\mathrm{N}$ sector } & $-0,0611$ & & 0,0146 & & $-0,2729$ & $* *$ & $-0,0040$ & & $-0,1717$ & & $-0,0448$ & \\
\hline & 0,1082 & & 0,0532 & & 0,2786 & & 0,0591 & & 0,1347 & & 0,0846 & \\
\hline \multirow[t]{2}{*}{ Tobin's Q } & 0,0538 & $* * *$ & 0,0471 & $* * *$ & 0,2514 & & 0,0837 & $* * *$ & $-0,0247$ & & 0,0152 & \\
\hline & 0,0200 & & 0,0148 & & 0,1134 & & 0,0219 & & 0,0268 & & 0,0190 & \\
\hline Total Sales over CS & 0,0267 & $* * *$ & 0,0112 & $*$ & 0,0434 & & 0,0326 & $* * *$ & $-0,0180$ & & 0,0004 & \\
\hline Total Debt over CS & 0,0123 & & 0,0074 & & 0,0586 & & 0,0127 & & 0,0200 & & 0,0094 & \\
\hline Observation & 1328 & & 1328 & & 212 & & 212 & & 856 & & 856 & \\
\hline R-squared & 0.1363 & & 0.0082 & & 0.3388 & & 0.1251 & & 0.2483 & & 0.0062 & \\
\hline Hausman test & & & 46.43 & & & & - & & & & 42.39 & \\
\hline p-value & & & 0.0000 & & & & - & & & & 0.0000 & \\
\hline Specification & & & $\overline{F E}$ & & & & FE & & & & FE & \\
\hline
\end{tabular}


In general, based upon observation of firms listed on the Jakarta Stock Exchange, we can find that over the full period under study, there is no significant correlation between internal finance and firm-level investment. This finding is interesting since it provide a different insight from several predictions, especially that of Tornell and Westermann (2002a, 2004). The behavior of both sectors in Indonesia is relatively comparable. This finding might be supported by the credit supply data, in which we can see that credit supply to the N-sector is higher than credit to the T-sector. In Graphs 2 and 3, outstanding investment credit from commercial banks to the $\mathrm{N}$-sector in total and foreign currency exceeded credit to the $\mathrm{T}$ sector for several years after the crisis hit. Data on the median of total debt over capital stock, as shown in Graph 10, also demonstrates that the N-sector consumed more debt than the Tsector in the post-crisis period. Recent analysis of the current condition of Indonesia's economy also shows that the tradable sector in Indonesia is still in collapse after ten years of crisis.

Despite cash-flow-investment sensitivity, this study also shows that Tobin's Q is not useful in predicting investment over both the full period and the pre-crisis period, while in the post-crisis period it is negatively correlated with investment. The higher value of firms is predicted as firms with lower levels of investment.

Total sales as a proxy for future profitability are related positively to investment over the full period and post crisis period. Another variable examined in the estimation is the working capital. Table 2 also shows that the working capital is related positively to investment.

This research also finds that debt is related positively to investment, with the correlation much higher in the pre-crisis period than in the post-crisis period. In other words, firms were much more exposed to external finance during the pre-crisis period than during the post-crisis period. This piece of evidence is consistent with trade-off theory (Modigliani and Miller 1958), which predicts that financing choices are irrelevant to investment decisions, as the capital market works perfectly, allowing firms to access external capital easily and without cost. In the pre-crisis period, listed firms in Indonesia preferred to use external rather than internal debt, thus neglecting informational and agency costs. In other words, firms in Indonesia tended to be opportunistic in the pre-crisis period.

As well as investment, this research is also concerned with the behavior of inventory. Table 3 shows the results of regression for inventory as a dependent variable; we find that 
cash flow for the $\mathrm{N}$-sector is always related negatively to inventory. This leads to the explanation that firms in the $\mathrm{N}$-sector are predicted to be able to finance short-term investment in their operational activities or inventory using internal finance. Meanwhile, firms in the T-sector have to access external finance to support their operational activities (inventory), especially in the post-crisis period.

Tobin's Q as a firm value variable is positively related to inventory in pre-crisis period, but is not significantly relevant in post-crisis period. The working capital as well as debt, is related negatively to inventory.

\subsubsection{Industrial Sectors Analysis}

The main idea of this section is to capture the effect of industrial sector on the relation between investment and internal liquidity. This paper considers industrial sectors by the definition of JXS, which is divided into 9 sub-sectors $^{18}$. Table (4) shows the results of regression for each sector estimates by employing the equation (3). One of the important finding from this section is that in most cases or sectors, debt is always positively and significantly related to investment. It means that for most sectors, debt is supposed to be important variable for sustaining their investment.

By graphical observation, it seems that sector 6 (property, real estate \& building construction sector) has a high investment volatility. Generally, due to the 1997 currency depreciation, firm investment level in sector 6 diminishes significantly.

\footnotetext{
${ }^{18}$ See JASICA classification as mentioned above
} 
Graph 11. Median of Investment over Capital Stock

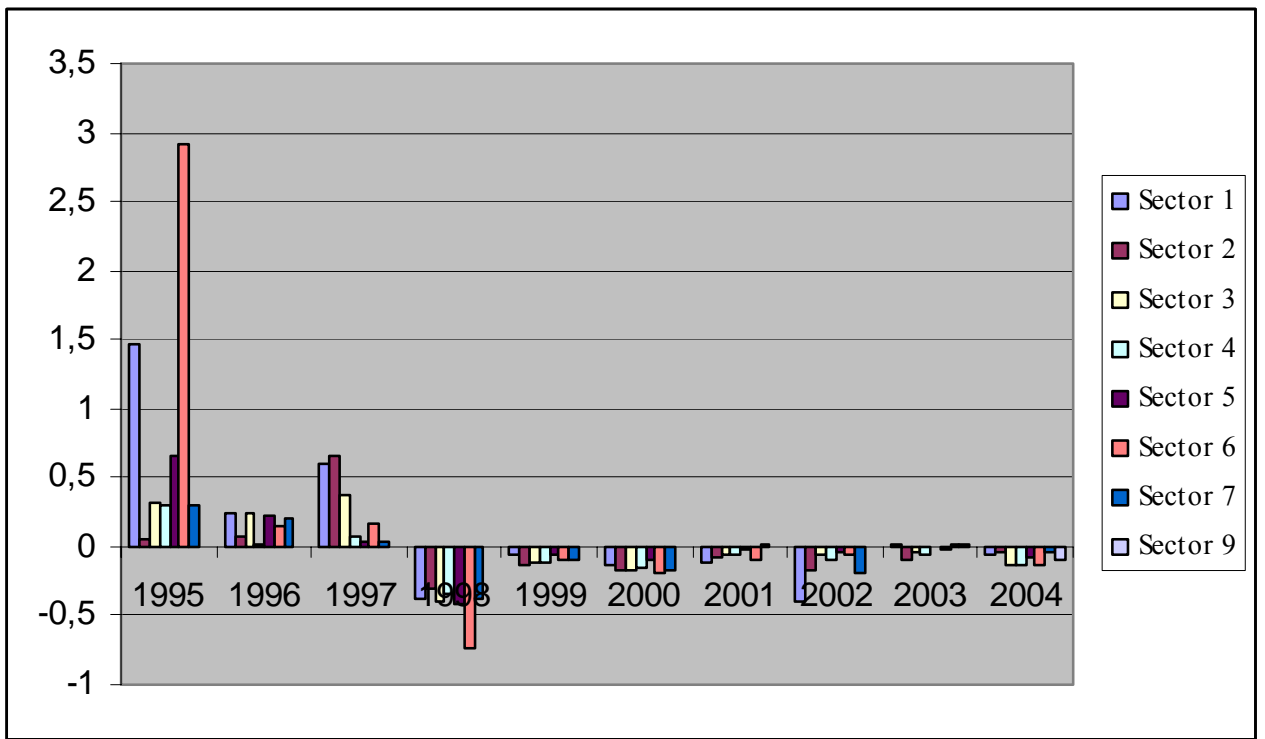

Source: author's calculation based on JSX's database and Indonesian Capital Market Directory provided by ECFIN

Sector $1=$ agriculture

Sector $2=$ mining

Sector $3=$ basic industry \& chemical

Sector $4=$ miscellaneous industry

Sector $5=$ consumer good industry

Sector 6 = property, real estate $\&$ building construction

Sector $7=$ infrastructure, utilities \& transportation

Sector $9=$ trade, service $\&$ investment

Graph 12. Median of the Change of Inventory over Capital Stock

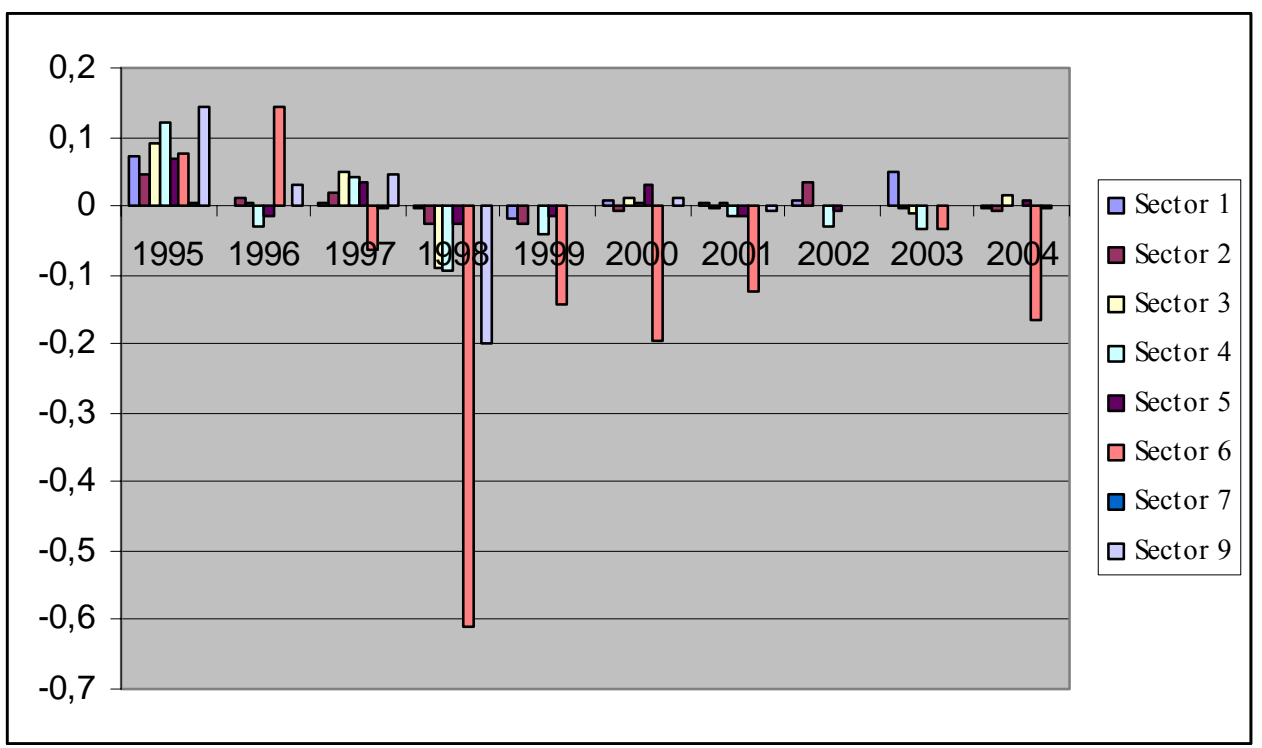

Source: author's calculation based on JSX's database and Indonesian Capital Market Directory provided by ECFIN 
Sector 1 = agriculture

Sector $2=$ mining

Sector $3=$ basic industry \& chemical

Sector $4=$ miscellaneous industry

Sector $5=$ consumer good industry

Sector $6=$ property, real estate $\&$ building construction

Sector $7=$ infrastructure, utilities \& transportation

Sector $9=$ trade, service $\&$ investment 


\begin{tabular}{|c|c|c|c|c|c|c|c|c|c|c|c|c|c|c|c|c|}
\hline \multirow{2}{*}{$\begin{array}{l}\text { Table 4. Regression fo } \\
\text { In this case, we use Ord } \\
\text { percent levels, respectiv } \\
\text { Sector } 1=\text { agriculture; } \\
\text { property, real estate \& } \\
\text { CS is capital stock } \\
\text { Cash Flow over CS } \\
\end{array}$} & \multicolumn{2}{|c|}{ Sector 1} & \multicolumn{2}{|c|}{ Sector 2} & \multicolumn{2}{|c|}{ Sector 3} & \multicolumn{2}{|c|}{ Sector 4} & \multicolumn{2}{|c|}{ Sector 5} & \multicolumn{2}{|c|}{ Sector 6} & \multicolumn{2}{|c|}{ Sector 7} & \multicolumn{2}{|c|}{ Sector 9} \\
\hline & $-0,3758$ & & $-0,4388$ & $* *$ & $-0,0082$ & & $-0,5357$ & $*$ & $-0,1017$ & & $-0,1270$ & & $-0,5434$ & & $-0,1003$ & \\
\hline & 0,3108 & & 0,1920 & & 0,0568 & & 0,3240 & & 0,1366 & & 0,7872 & & 0,3467 & & 0,1361 & \\
\hline Tobin Q over CS & 0,0916 & & $-0,0062$ & & $-0,0675$ & & $-0,1507$ & $* * *$ & 0,0520 & & $-0,0638$ & & $-0,0636$ & & 0,0810 & \\
\hline & 0,1078 & & 0,1401 & & 0,0789 & & 0,0577 & & 0,0737 & & 0,2482 & & 0,0732 & & 0,0547 & \\
\hline Total Sales over CS & $-0,0449$ & & $-0,1075$ & & $-0,0519$ & $* *$ & 0,0188 & & 0,0769 & $*$ & 0,0490 & & 0,1176 & & $-0,0102$ & \\
\hline & 0,0676 & & 0,0763 & & 0,0196 & & 0,0282 & & 0,0405 & & 0,1325 & & 0,1419 & & 0,0167 & \\
\hline $\begin{array}{l}\text { Working Capital over } \\
\text { CS }\end{array}$ & 0,3847 & $* * *$ & 0,3949 & $* * *$ & 0,0589 & $* *$ & $-0,0060$ & & 0,0382 & & 0,0465 & & $-0,0100$ & & 0,1276 & $* * *$ \\
\hline & 0,1257 & & 0,1128 & & 0,0252 & & 0,0740 & & 0,0548 & & 0,0738 & & 0,1875 & & 0,0403 & \\
\hline Total Debt CS & 0,3319 & $* * *$ & 0,3604 & $* * *$ & 0,0819 & $* * *$ & 0,0997 & $* *$ & 0,0809 & & 0,1166 & $* *$ & 0,8191 & $* * *$ & 0,1668 & $* * *$ \\
\hline & 0,1107 & & 0,1287 & & 0,0322 & & 0,0449 & & 0,0520 & & 0,0564 & & 0,1727 & & 0,0522 & \\
\hline Constant & $-0,4662$ & $* * *$ & $-0,3268$ & $*$ & 0,0768 & & 0,0472 & & $-0,2986$ & $* * *$ & $-0,2020$ & & $-0,6531$ & $* * *$ & $-0,3435$ & $* * *$ \\
\hline & 0,1738 & & 0,1933 & & 0,0845 & & 0,0858 & & 0,1070 & & 0,3230 & & 0,2095 & & 0,0886 & \\
\hline Observation & 38 & & 47 & & 374 & & 293 & & 221 & & 94 & & 67 & & 194 & \\
\hline R-Squared & 0.4044 & & 0.3165 & & 0.0476 & & 0.0447 & & 0.1590 & & 0.0833 & & 0.5158 & & 0.1861 & \\
\hline
\end{tabular}


Meanwhile, by observing graph 13 below, it seems that due to currency depreciation firms in sector 2 (mining) decrease significantly their cash flow. Firms in sector 4 (miscellaneous industry), which include industries such as machinery and heavy equipment, automotive and components, cable and electronics, have high level of cash flow.

Graph 13. Median of Cash Flow over Capital Stock

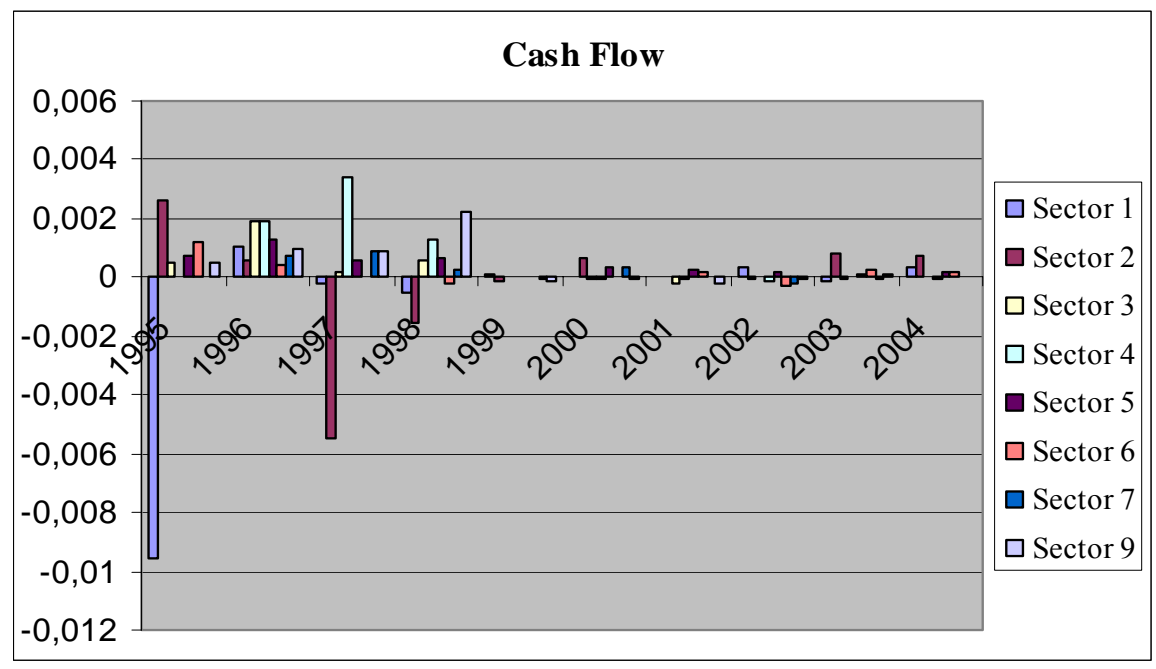

Source: author's calculation based on JSX's database and Indonesian

Capital Market Directory provided by ECFIN

Sector 1 = agriculture

Sector $2=$ mining

Sector 3 = basic industry $\&$ chemical

Sector $4=$ miscellaneous industry

Sector $5=$ consumer good industry

Sector 6 = property, real estate $\&$ building construction

Sector $7=$ infrastructure, utilities \& transportation

Sector $9=$ trade, service $\&$ investment

In graph (14) below, we can see that firms in sector 5 (consumer good) have relatively high market expectation. It seems that firms in sector 5 have high performance in the capital market. 
Graph 14. Median of Tobin Q

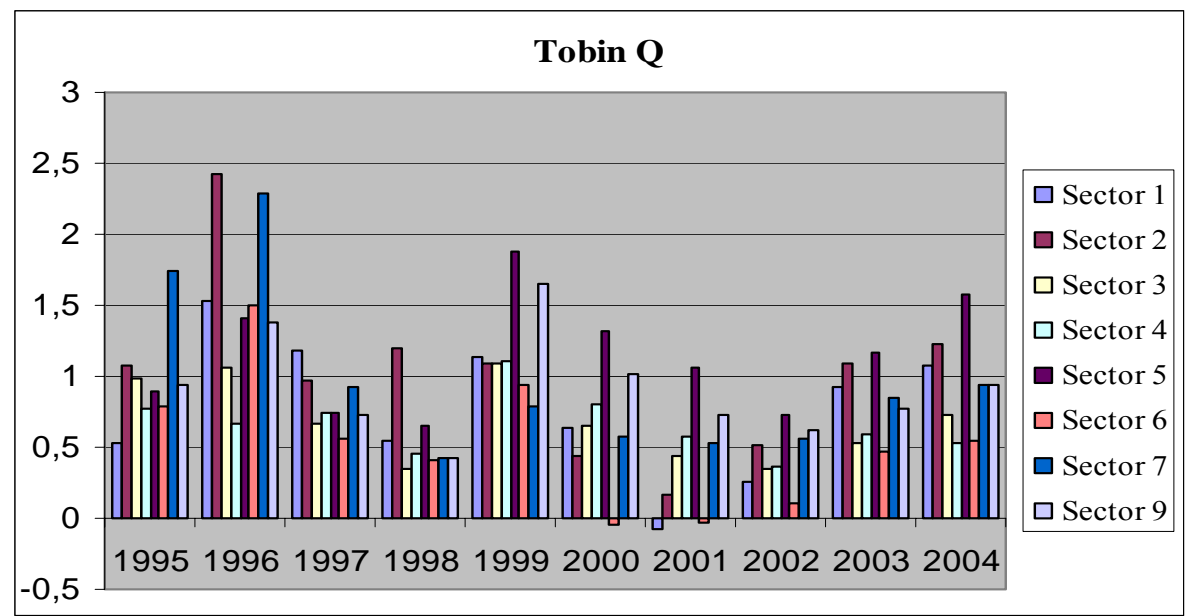

Source: author's calculation based on JSX's database and Indonesian Capital Market Directory provided by ECFIN

Sector 1 = agriculture

Sector 2 = mining

Sector $3=$ basic industry \& chemical

Sector $4=$ miscellaneous industry

Sector $5=$ consumer good industry

Sector $6=$ property, real estate $\&$ building construction

Sector $7=$ infrastructure, utilities \& transportation

Sector $9=$ trade, service $\&$ investment

By data descriptive in graph (15) below, we find that sector 9 (trade, service and investment) gain most profitable revenue among other sector. Currency crisis does not reduce the sales of the firms in this sector.

Graph 15. Median of Total Sales over Capital Stock

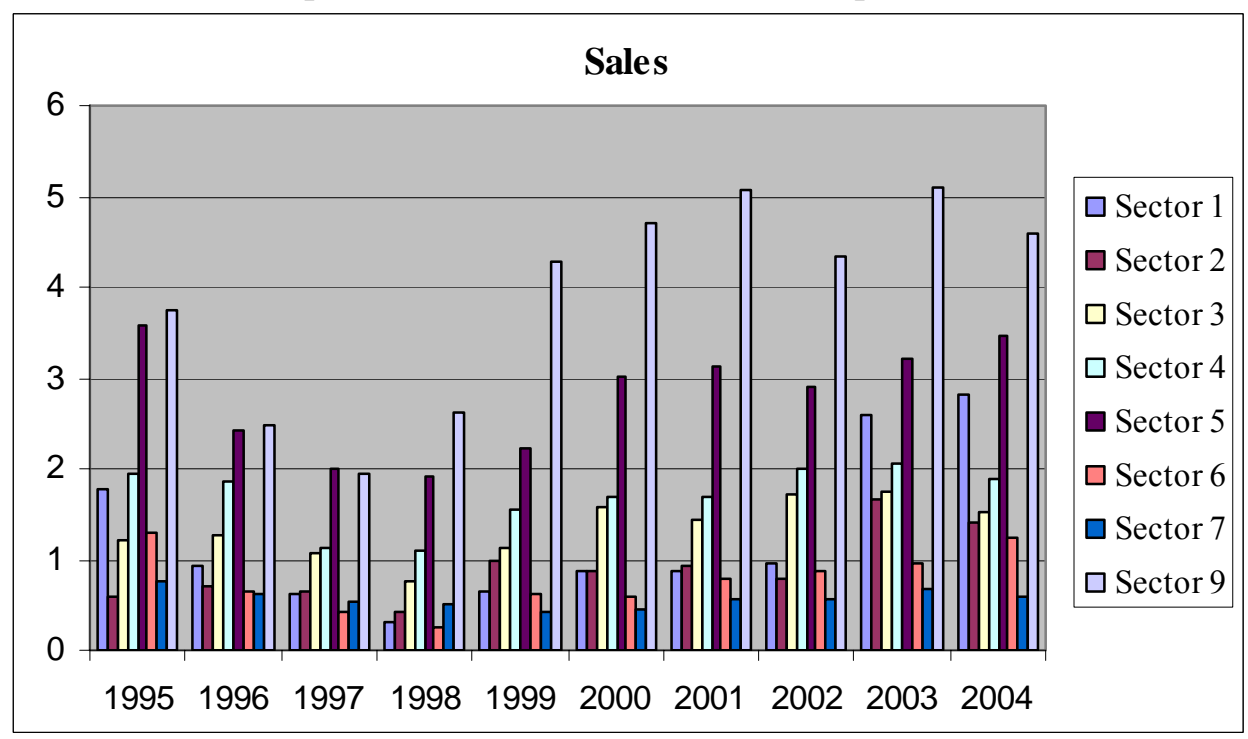

Source: author's calculation based on JSX's database and Indonesian 
Capital Market Directory provided by ECFIN

Sector $1=$ agriculture

Sector 2 = mining

Sector 3 = basic industry $\&$ chemical

Sector $4=$ miscellaneous industry

Sector $5=$ consumer good industry

Sector $6=$ property, real estate $\&$ building construction

Sector $7=$ infrastructure, utilities \& transportation

Sector $9=$ trade, service $\&$ investment

In term of working capital, in the aftermath of crisis, firms in sector agriculture have smallest ratio of working capital to capital stock among other sectors.

Graph 16. Median of Working Capital over Capital Stock

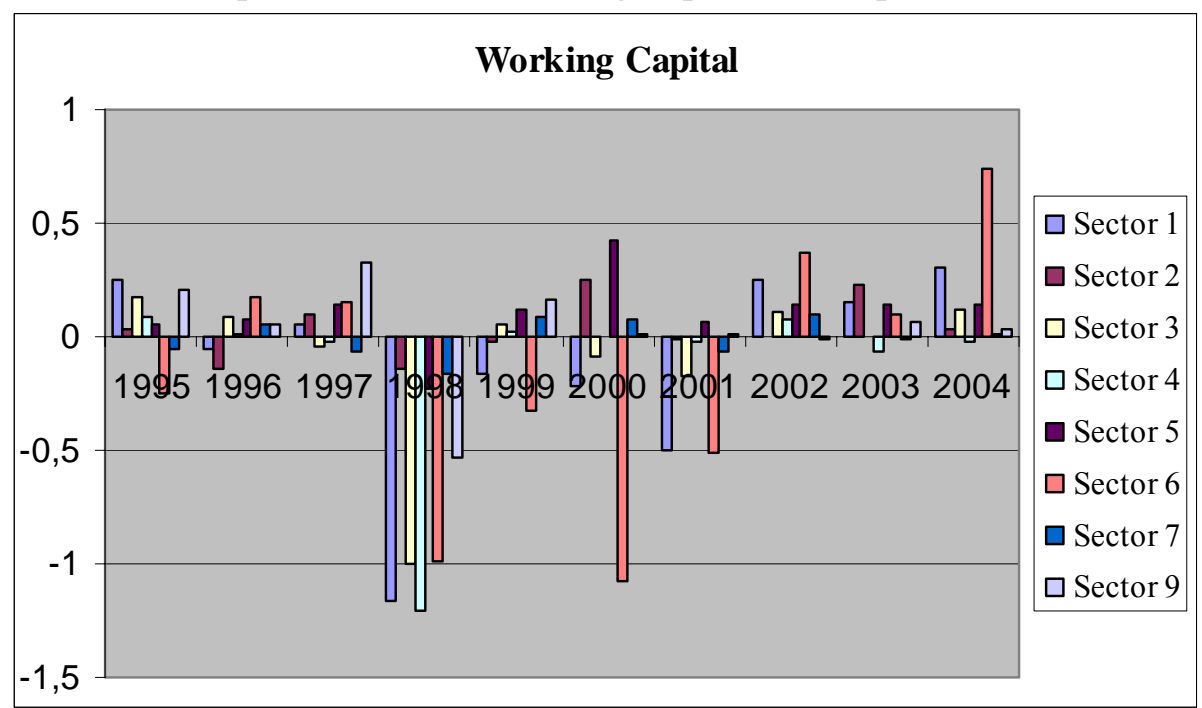

Source: author's calculation based on JSX's database and Indonesian

Capital Market Directory provided by ECFIN

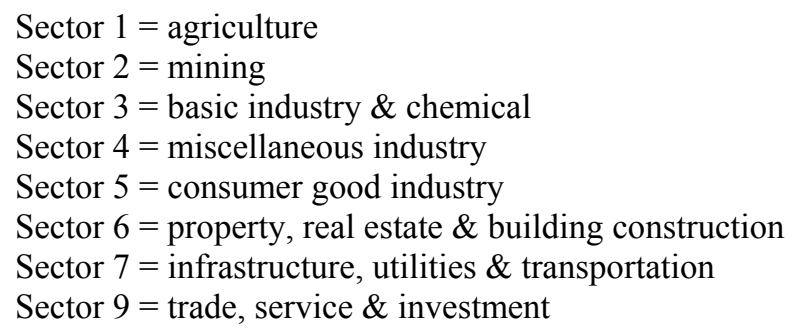

In the following graph (17), it is important to note that property sector has a high ratio of debt which could be risky. Property sector is basically an unproductive sector. This descriptive data support the regression result due to the role of property sector (non-tradable sector) in risk to exacerbate crisis in Indonesia. 
Graph 17. Median of Total Debt over Capital Stock

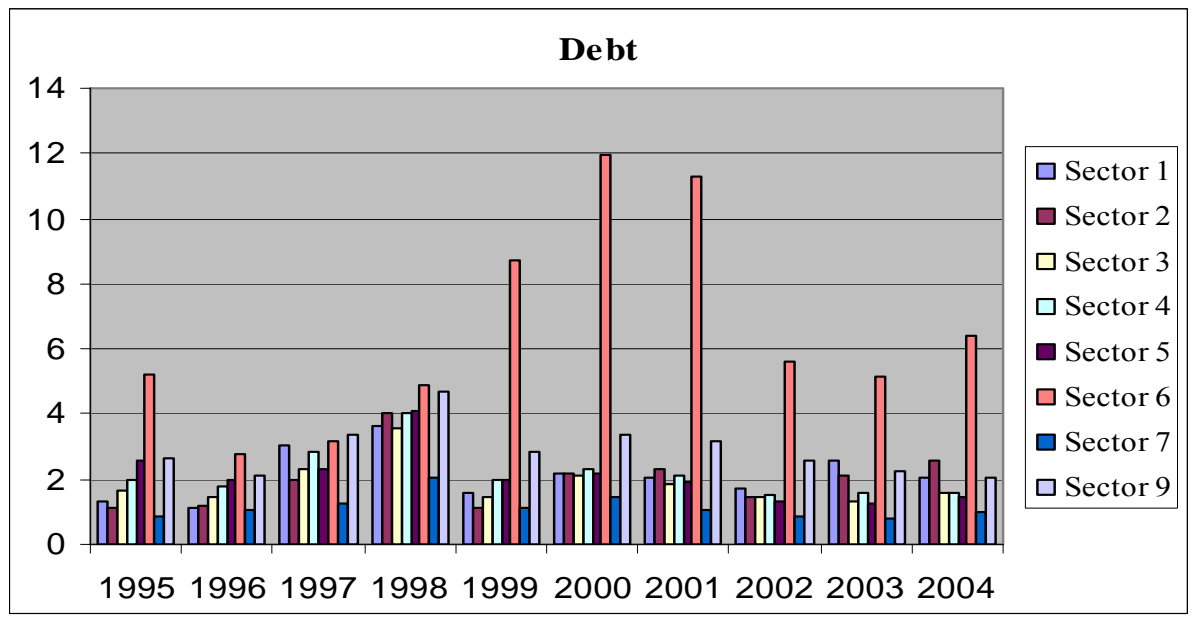

Source: author's calculation based on JSX's database and Indonesian

Capital Market Directory provided by ECFIN

Sector $1=$ agriculture

Sector $2=$ mining

Sector $3=$ basic industry \& chemical

Sector $4=$ miscellaneous industry

Sector $5=$ consumer good industry

Sector $6=$ property, real estate $\&$ building construction

Sector 7 = infrastructure, utilities \& transportation

Sector $9=$ trade, service $\&$ investment

Data from Bank Indonesia as shown in graph 3 above describes how non-tradable sector actually have been more exposed to foreign debts than T sector. Data on outstanding credit of commercial banks to investment in foreign currency shows there is an inverse fluctuation between supply of credit to $\mathrm{T}$ and $\mathrm{N}$ sector. Before crisis $\mathrm{T}$-sector has had more foreign debt than $\mathrm{N}$-sector, but in post crisis period $\mathrm{N}$-sector exceeded $\mathrm{T}$-sector.

By observing data of the 200 greatest debtor collected by IBRA (Indonesian Banking Restructuring Agency), we can see that the proportion of $\mathrm{T}$ and $\mathrm{N}$ sector is comparable. As shown in appendix, there are 100 firms from $\mathrm{N}$-sector and 95 firms from $\mathrm{T}$-sector from the 200 greatest obligors under IBRA. Among 100 non-tradable firms, 54 firms are firm in service industry, and 28 from trade/hotel/restaurant industry, 7 from transportation/warehouse/telecommunication industry, and 11 from construction. In tradable sector, 83 firms are firms in manufacture, 11 firms are agribusiness and 1 firm from mining sector $^{19}$.

\footnotetext{
${ }^{19}$ For detail data, see appendix
} 


\section{Conclusion}

The main finding of this paper is that in the pre- and post crisis period, both the T-and $\mathrm{N}$-sectors experience no significant financial constraints. These findings are relatively different from previous studies, especially that by Tornell and Westermann (2002a, 2004). However, it seems that firms in the non-tradable sector are more easily released from severe problems than the tradable sector, since firms in the tradable sector have complicated obstacles to undertaking their business. The tradable sector, or real sector, therefore endured very difficult conditions for several years after the crisis hit.

There are two normative implications of our study. First, from an academic point of view, this study contributes an answer to the question of whether the sensitivity of investment to financial factors differs with the heterogeneity of firms' characteristics. Second, from a policy point of view, the existence of a financial channel can shed light on the sources of volatility in corporate investment behavior. This can guide policymakers in their attempts to resolve the problem faced by firms of accessing sufficient funding to support their business activities, especially where there is a question of inducing firm-level investment. In practical terms, this finding could help explain why firm-level investment in post-crisis Indonesia is still in collapse, as well as allowing us to identify those heterogeneity factors inducing the severe condition of Indonesia's economy recently.

By employing the innovation of FHP (1988) on the sensitivity relation between firmlevel investment and its internal liquidity, this paper supports the argument that there exist asymmetric financing opportunities between the $\mathrm{T}$ - and $\mathrm{N}$-sectors which could threaten economic stability.

By qualitative analysis, this research finds that in terms of firm profitability and debt, there are very different responses among firms in the T-and N-sectors to the 1997 financial crisis. In general, the T-sector has higher profitability with lower levels of debt than the Nsector. Both variables are important indicators for examining economic vulnerability from a micro-level perspective.

This research therefore provides two pieces of evidence that could be significant for further research on the field of firms' behavior in Indonesia. First, both the T- and N-sectors experience no significant financing constraints in the pre- and post-crisis period. However, business activities have not yet been released from deep crisis. This paper shows that the Tsector has many more financial constraints than the N-sector in the post-crisis period. Second, 
firms in Indonesia still generally prefer external debt to equity when financing their investment activities, even in this post-crisis period. This evidence leads to the conclusion that Indonesia's economy is still vulnerable and prone to financial depression.

However, one important limitation on this investigation is data availability. Some variables are constructed manually, and could thus contain important discrepancies in two areas. First, poor availability of data leads to limited analysis, and second, efforts to provide data manually could involve serious errors, which are commonly present in manual work. Another important problem concerning the data is its high volatility, especially in investment, sales, and debt. To deal with this problem, we excluded many companies containing volatile data in certain variables. As a consequence, however, the number of firms examined in this study was diminished.

Further investigation of this topic requires an improvement in econometrical methods, so as to yield more rigorous results. Moreover, analyzing the asymmetric financing opportunities between different groups of firms could be fruitful for gaining a better understanding of firms' behavior as related to the financial fragility and economic vulnerability in Indonesia. In future research, it would be interesting to develop the theme of asymmetric financing opportunities to include different groups, such as family and non-family firms or firms with bank and non-bank relations**.

\section{References}

Azis, Iwan Jaya. 2004. Credit market frictions and balance sheet effects, mimeo, Cornel University.

2002. What would have happened in Indonesia if different economic policies had been implemented when the crisis started? Asian Economic Papers, volume 1, Issue 2, Spring.

2001. Modelling crisis evolution and counterfactual policy simulations: a country case study, ADB Institute Working Paper Series, No.23.

Bernanke, Ben S and Gertler, Mark, 1995. Inside the black box: the credit channel of monetary policy transmission, Journal of Economic Perspectives, American Economic Association, vol. 9(4), pages 27-48, Fall.

. 1986. Agency costs, collateral, and business fluctuations, NBER Working Papers 2015, National Bureau of Economic Research, Inc.

Bernanke, B., Gertler, M. and Gilchrist, S. 1998. The financial accelerator in a quantitative business cycle framework, Working Papers 98-03, C.V. Starr Center for Applied Economics, New York University 
Bruinshoofd, Allard. 2003. Corporate investment and financing constraints: connections with cash management, DNB Staff Report no.110, De Nederlandsche Bank, The Netherlands.

Caggese, Andrea. 2005. Testing financing constraints on firm investment using variable capital, mimeo, Department of Economics, Pompeu Fabra University, Barcelona, Spain

Chirinko, Robert S., Ulf von Kalckreuth. 2002. Further evidence on the relationship between firm investment and financial status, Discussion paper, No.28/02, Economic Research Centre of the Deutsche Bundesbank, Frankfurt, Germany

Chirinko, Robert S. and Schaller, Huntley. 1996. Business fixed investment and "bubbles": the Japanese case, Economics Series 28, Institute for Advanced Studies.

Cleary, Sean W. 1999. The relationship between firm investment and financial status, Journal of Finance, 54, pp. 673-692.

Espanol, Paula, 2005, Why exportable firms can be financially constrained in a recently liberalized economy? A puzzle based on Argentinean firms during the 1990s, working paper, PSE (Paris-Jourdan Sciences Economiques), Paris, France.

Fukunari Kimura, Fukunari and Kozo Kiyota. 2004. Foreign-owned versus domesticallyowned firms: economic performance in Japan, Discussion Paper No. 506, Research Seminar in International Economics, School of Public Policy, The University of Michigan, US.

Fazzari, Steven; Piero Ferri; Edward Greenberg. 2003. Cash flow, investment, and KeynesMinsky cycles, Working Paper, Washington University in St. Louis (USA).

Fazzari, Steven M., Bruce C. Petersen. 1993. Working capital and fixed investment: new evidence on financing constraints, The RAND Journal of Economics, Vol.24, No.3, 328342.

Fazzari, Steven M., Glenn R. Hubbard and Bruce C. Petersen. 1988. Financing constraints and corporate investment, Brookings Papers on Economic Activity no.1, pp. 141-195.

Ganesh-Kumar A., Kunal Sen and Rajendra Vaidya. 2002. Does the source of financing matter? financial markets, financial intermediaries and investment in India, Journal of International Development, 14(2), pp.211-228.

Gertler, Mark and Simon Gilchrist.1994. Monetary policy, business cycles, and the behavior of small manufacturing firms, Quarterly Journal of Economics no.109, pp. 309-340.

Géczy, C., B.A. Minton, and C. Schrand. 1997. Why firms use currency derivatives, Journal of Finance, 52, 1323-1354.

Hoshi, Takeo, Anil Kashyap and David Scharfstein. 1991. Corporate structure, liquidity, and investment: evidence from Japanese industrial groups, The Quarterly Journal of Economics, Vol. 106, No. 1, pp.33-60

Hsiao, Cheng and A.Kamil Tahmiscioglu. 1997. A panel analysis of liquidity constraints and firm investment, Journal of the American Statistical Association, Vol.92, No.438, pp 455-465

Hubbard, Glenn R. 1998. Capital-market imperfections and investment, Journal of Economic Literature, American Economic Association, vol. 36(1), pages 193-225, March. 
Jensen, M.C., and W.H. Meckling. 1976. Theory of the firm: managerial behavior, agency costs and ownership structure, Journal of Financial Economics, Vol. 3, No. 4, pp. 305360 .

Juda, Agung, Bambang Kusmiarso, Bambang Pramono, Erwin G. Hutapea, Andry Prasmuko, Nugroho Joko Prastowo. 2000. Credit crunch in Indonesia in the aftermath of the crisis: facts, causes and policy implications, Working Paper, Directorate of Economic Research and Monetary Policy Bank Indonesia.

Kaplan, Steven N. and Luigi Zingales. 1997. Do investment-cash flow sensitivities provide useful measures of financing constraints?, The Quarterly Journal of Economics, Vol. 112, No.1, pp. 169-215.

Paul Krugman, Paul. 1998. What happened to Asia?, mimeo, MIT

Modigliani, Franco, and Merton H. Miller. 1958. The cost of capital, corporation finance and the theory of investment, American Economic Review 48, 261-297.

Myers, Stewart and Nicholal S. Majluf. 1984. Corporate financing and investment decisions when firms have information that investors do not have, Journal of Financial Economics, Vol. 13: 187-221.

Mills, Karen, Steven Morling and Warren Tease, 1994. The influence of financial factors on corporate investment, Research Discussion Paper, No.9402, Economic Analysis Department, Reserve Bank of Australia, Australia

Mizen, Paul and Philip Vermeulen. 2005. Corporate investment and cash flow sensitivity what drives the relationship?, Working Paper Series, No.485

Tornell, Aaron and Frank Westermann. 2004. The positive link between financial liberalization, growth and crisis, CESifo Working Paper, Number 1164, MunichGermany.

. 2002a. Credit market imperfections in Middle Income Countries, CESifo Working Paper, Munich-Germany.

. 2002b. Boom-bust cycle in middle income countries: facts and explanations, IMF Staff Paper, Volume 49, Special Issue.

Whited, T. 1992. Debt, liquidity constraints, and corporate investment: evidence from panel data, Journal of Finance, 47, 1425-1459. 


\begin{tabular}{|c|c|c|c|}
\hline \multicolumn{4}{|c|}{ Apendix } \\
\hline & Non-tradable Sector & & Tradable Sector \\
\hline & $\underline{\text { Service }}$ & & Manufacturing \\
\hline 1 & ABS Industry Indonesia PT & 1 & Adikara Nirmala PT \\
\hline 2 & Alfa Goldland Realty PT & 2 & Andatu Lestari Plywood PT \\
\hline 3 & Authotrans Perkasa Indonesia PT & 3 & Apac Inti Corpora PT \\
\hline 4 & Bahana Bina Ventura PT & 4 & Artika Optima Inti PT \\
\hline 5 & Bahana Investa Argha PT & 5 & Asriland PT \\
\hline 6 & Bahana Pembina Usaha Ina. & 6 & Bakrie\&Brothers PT \\
\hline 7 & Bakrie International Finance & 7 & Bante Java Persada, PT \\
\hline 8 & Bakrie Investindo PT & 8 & Batasan PT \\
\hline 9 & Bekasi Fajar Industrial Estate, PT & 9 & Bentoel Prim, PT \\
\hline 10 & Bentala Lestari, PT & 10 & Bhirawa Steel, PT \\
\hline 11 & Bentala Mahaya, PT & 11 & Bimantara Citra, PT \\
\hline 12 & BNI Securities, PT & 12 & Buanagraha Artha Prima, PT \\
\hline 13 & Boga Nandini Andrawina, PT & 13 & Budiono Widodo \\
\hline 14 & Bonauli Realestate, PT & 14 & Bukti Jonggol Asri, PT \\
\hline 15 & Bunas Finance Indonesia TBK, PT & 15 & Bukit Welirang Indah, PT \\
\hline 16 & Citra Marga Finance BV & 16 & Bumi Angkasa Textile Indonesia, PT \\
\hline 17 & Danamon Finance, PT & 17 & Chandra Asri, PT \\
\hline 18 & Danareksa, PT & 18 & Cisadane Raya Chemicals, PT \\
\hline 19 & Datakom Asia, PT & 19 & Daya Besar Agung, PT \\
\hline 20 & Deemte Sakti International & 20 & Detta Marina, PT \\
\hline 21 & Dhamala Intiutama Int'l BV. PT & 21 & Dok \& Perkapalan Kodja Bahari, PT \\
\hline 22 & Dharmala Sakti Sejahtera, PT & 22 & Ekadharma Garmentama, PT \\
\hline 23 & Duta Anggada Realty, PT & 23 & Fajar Surya Perkasa, PT \\
\hline 24 & Eastglobe LTD & 24 & Frans Putratex PT \\
\hline 25 & Estika Yasakelola, PT & 25 & Gema Lapik PT \\
\hline 26 & Global Toserco LTD & 26 & Gemala Industrie, LTD \\
\hline 27 & Graha Sarana Pratama PT (Suryapaloh) & 27 & Griri Asih Indah, PT \\
\hline 28 & Indomas Pacific Permai, PT & 28 & Giri Asih Jaya PT \\
\hline 29 & Indopac Finance & 29 & Gunawan Textindo PT \\
\hline 30 & Inti Karsa Daksa, PT & 30 & Hargas Industries IND PT \\
\hline 31 & Jababeka Interantional BV & 31 & Hartono Istana Electronics PT \\
\hline 32 & Kondowana Safari PT & 32 & Industri Galvanealmas, PT \\
\hline 33 & Mandara Permai PT & 33 & Intear Pretindo Inti Citra, PT \\
\hline 34 & Metropolitant Land PT & 34 & Interworld Steel Mills Indonesia, PT \\
\hline 35 & Modernland Realty TBK PT & 35 & Inti Texturindo Raya, PT \\
\hline 36 & Multi Angsana Ganda PT & 36 & IPTN \\
\hline 37 & Nelson Investment INT, LTD & 37 & Jakarta Cakra Tunggal Steel Mills PT \\
\hline 38 & Ometraco Multi Artha PT & 38 & Jakarta Kyoei Steel \\
\hline 39 & Pasific Interantional Finance PT & 39 & Jindo Kordeco Heavy IND, PT \\
\hline 40 & Primaswadana Perkasa Finance PT & 40 & Kalhold Utama, PT \\
\hline 41 & Putra Surya Multidana TBK, PT & 41 & Kalimanis Plywood IND, PT \\
\hline 42 & Putra Surya Perkasa TBK, PT & 42 & Karawang Utama, PT \\
\hline 43 & Risjad Brasali Styrindo PT & 43 & Kertas Basuki Rachmat PT \\
\hline 44 & Risjadson PT & 44 & Kertas Leces PT \\
\hline
\end{tabular}




\begin{tabular}{|c|c|c|c|}
\hline 45 & Salindo Perdana F. PT & 45 & Kiani Kertas PT \\
\hline 46 & Sanggraha Dhika PT & 46 & Komunikasi Selular Indonesia PT \\
\hline 47 & Segitiga Atrium, PT & 47 & Langgeng Makmur I TBK, PT \\
\hline 48 & Segitiga Plaza Hotel, PT & 48 & Lucky Star Navigation Corp. \\
\hline 49 & Sewu Agro Investama PT & 49 & Mahliagai Senantiasa Makmur \\
\hline 50 & Sinar Slipi Sejahtera PT & 50 & Maligi Spinning Mills \\
\hline 51 & Sumbermitra Sarana Realtindo PT & 51 & Mitra Laras Serasi PT \\
\hline 52 & Surya Citra Televisi Indonesia PT & 52 & Multi Strada Arah Sarana, PT \\
\hline 53 & Tirtamas Majutama PT & 53 & Multikarsa Investama, PT \\
\hline \multirow[t]{3}{*}{54} & Welwin Finance, Hongkong & 54 & Nasio Dutamitra Electric PT \\
\hline & & 55 & Nusantara Playwood PT \\
\hline & Trade/Hotel/Restaurant & 56 & Omedata Electronics, PT \\
\hline 1 & Aneka Agroprasidha PT & 57 & Palwa Minatama Jaladri PT \\
\hline 2 & Aneka Bumi Prasidha PT & 58 & Pancashindu Abadi PT \\
\hline 3 & Bakrie Nirwana Resort PT & 59 & Pangaji Mario Refconindo PT \\
\hline 4 & Banigati Betegak, PT & 60 & Panggung Electric Corp PT \\
\hline 5 & Bina Perkasa Indograha, PT & 61 & Papyrus Sakti PT \\
\hline 6 & Caterison Sukses, PT & 62 & Poyfin Canggih PT \\
\hline 7 & Citra Rapi Hotel, PT & 63 & Polyprima Karyareksa PT \\
\hline 8 & Citrasarana Graharealty Corp. & 64 & Prajogo Pangestu \\
\hline 9 & Dewata Agung Wibawa & 65 & Samless Pipe Indonesia Jaya PT \\
\hline 10 & Dharma Niaga (Persero), PT & 66 & Sebasli Pratama \\
\hline 11 & Dharmala Sakti Pancagraha & 67 & Semen Baturaja, PT \\
\hline 12 & Griya Permata Lestari & 68 & Semen Cibinong, PT \\
\hline 13 & Humpuss PT & 69 & Semen Gombong PT \\
\hline 14 & Humpuss Terminal P, PT & 70 & Serindo Djaja Marmer Industries, PT \\
\hline 15 & Mandiri Citrasejati Hotel PT & 71 & Sipatex Putri Lestari PT \\
\hline 16 & Mas Murni IND, PT & 72 & Sragen Abadi Tekstil PT \\
\hline 17 & Moeladi PT & 73 & Staco Arta Karya PT \\
\hline 18 & Mulia Intan Lestari, PT & 74 & Telekomindo Primabhakti PT \\
\hline 19 & Pengembangan Pariwisata Lombok PT & 75 & Tensindo Sejati PT \\
\hline 20 & Permadani Khatulistiwa Nusantara PT & 76 & Terang Kita PT \\
\hline 21 & Prabu Budi Mulia PT & 77 & The First National Glassware PT \\
\hline 22 & Ramasari Surya Persada PT & 78 & Timor Putra Nasional PT \\
\hline 23 & Sentra Sintetika Jaya & 79 & Usaha Gedung Bimantara PT \\
\hline 24 & Sinn Bualuang Public Company LTD & 80 & Wahana Perkasa Auto Jaya PT \\
\hline 25 & Staco Graha PT & 81 & Yason Pernana PT \\
\hline 26 & Swastika Hijau Makmur & 82 & Continental Sinar Steel PT \\
\hline 27 & Tahta Medan PT & 83 & Sandatex PT \\
\hline \multirow[t]{2}{*}{28} & Tirtamas Comexindo PT & & \\
\hline & Transportation/Warehouse/Telecomunication & & Agribusiness \\
\hline 1 & Asia Cellular Sattellite PT & 1 & Arindo Tri Sejahtera \\
\hline 2 & Badiradaya Sentranusa PT & 2 & Bali Raya PT \\
\hline 3 & Merpati Nusantara PT & 3 & Central Pertiwi Bahari, PT \\
\hline 4 & Pasifik Satelit Nusantara PT & 4 & Gerak Maju PT \\
\hline 5 & Satelindo PT & 5 & Hasil Cipta Laut PT \\
\hline 6 & Sempati Air PT & 6 & Ika Muda Seafood International, PT \\
\hline \multirow[t]{2}{*}{7} & Widya Duta Informindo, PT & 7 & Kiani Lestari PT \\
\hline & & 8 & Nusantara Ampera Bakti PT \\
\hline
\end{tabular}




\begin{tabular}{|r|l|r|l|}
\hline & Construction & 9 & Riau Andalan Kertas PT \\
\hline 1 & Batanghari Persada, PT & 10 & Riau Prima Energi PT \\
\hline 2 & Bukit Sentul TBK, PT & 11 & Tuwung Agung PT \\
\hline 3 & Hutama Karya, PT & & Mining \\
\hline 4 & Karyagraha Elektrindo PT & 1 & Humpuss, INC \\
\hline 5 & Lippo Karawaci TBK, PT & & \\
\hline 6 & Marga Nurindo Bhakti PT & \\
\hline 7 & Margabumi Matraraya PT & \\
\hline 8 & Samurindo Swadaya Sejatera AP & & \\
\hline 9 & Swadharma Primautama PT & & \\
\hline 10 & Swaraeka Prasetia PT & & \\
\hline 11 & Istaka Karya PT & & \\
\hline & & & \\
\hline & NN & & \\
\hline 1 & Ceka Jawa Industri, PT & & \\
\hline 2 & Indobuildco, PT & & \\
\hline 3 & Internusa Keramik, PT & & \\
\hline 4 & Inti Keramik Alamsri, PT & & \\
\hline 5 & Risjad Brasali Peroxid & \multicolumn{2}{|l|}{} \\
\hline Source: Annual Report 2000, Indonesian Banking Restructuring Agency (IBRA) \\
\hline
\end{tabular}

